Article

\title{
Carbon Xerogels Hydrothermally Doped with Bimetal Oxides for Oxygen Reduction Reaction
}

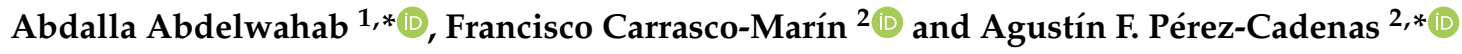 \\ 1 Materials Science and Nanotechnology Department, Faculty of Postgraduate Studies for Advanced Sciences, \\ Beni-Suef University, Beni-Suef 62511, Egypt \\ 2 Carbon Materials Research Group, Department of Inorganic Chemistry, Faculty of Sciences, \\ University of Granada, Campus Fuentenueva s/n, ES18071 Granada, Spain \\ * Correspondence: aabdelwahab@psas.bsu.edu.eg (A.A.); afperez@ugr.es (A.F.P.-C.)
}

Received: 27 June 2019; Accepted: 27 July 2019; Published: 31 July 2019

\begin{abstract}
A total of two carbon xerogels doped with cobalt and nickel were prepared by the sol-gel method. The obtained carbon xerogels underwent further surface modification with three binary metal oxides namely: nickel cobaltite, nickel ferrite, and cobalt ferrite through the hydrothermal method. The mesopore volumes of these materials ranged between 0.24 and $0.40 \mathrm{~cm}^{3} / \mathrm{g}$. Moreover, there was a morphology transformation for the carbon xerogels doped with nickel cobaltite, which is in the form of nano-needles after the hydrothermal process. Whereas the carbon xerogels doped with nickel ferrite and cobalt ferrite maintained the normal carbon xerogel structure after the hydrothermal process. The prepared materials were tested as electrocatalysts for oxygen reduction reaction using $0.1 \mathrm{M} \mathrm{KOH}$. Among the prepared carbon xerogels cobalt-doped carbon xerogel had better electrocatalytic performance than the nickel-doped ones. Moreover, the carbon xerogels doped with nickel cobaltite showed excellent activity for oxygen reduction reaction due to mesoporosity development. $\mathrm{NiCo}_{2} \mathrm{O}_{4} / \mathrm{Co}-\mathrm{CX}$ showed to be the best electrocatalyst of all the prepared electrocatalysts for oxygen reduction reaction application, exhibiting the highest electrocatalytic activity, lowest onset potential $\mathrm{E}_{\text {onset }}$ of $-0.06 \mathrm{~V}$, and the lowest equivalent series resistance (ESR) of $2.74 \Omega$.
\end{abstract}

Keywords: carbon gels; mesoporosity; electrocatalysis; oxygen reduction reaction

\section{Introduction}

The energy problem is one of the most important challenges the world is facing right now. Finding new sources of energy production and how to store this energy has become a major challenge. Lithium ion batteries are a kind of batteries that are used in portable electronics and electric vehicles [1]. Although lithium ion battery produces electricity with high energy density and low self-discharge, it presents some hazards as it contains a flammable electrolyte.

Fuel cells are electrochemical devices that are able to convert chemical energy into electrical energy when fuel and oxidant are supplied [2]. According to their working mechanism, fuel cell bears similarities in both batteries and engines, however, it has superior advantages as it does not need recharging and generates drinking water when the used fuel is hydrogen, so, it is considered as a "zero emission engine." Because it is environmentally friendly, fuel cells find commercial application in transportation, stationary power generation, and in low power portable devices. Fuel cells are facing some difficulties that delay its entry into the market. These difficulties can be attributed to economic factors, materials designing problem, and inadequacies in electrochemical devices operation $[2,3]$.

The fuel cell is a galvanic cell that consists of two electrodes, anode and cathode. The anodic fuel cell reaction is either the direct oxidation of hydrogen or the oxidation of methanol. The cathodic fuel cell reaction is usually oxygen reduction reaction (ORR) and in most cases the source of oxygen is 
air. The major factor that limits the fuel cell performance is the cathodic oxygen reduction reaction (ORR), as it consists of several steps in which molecular oxygen dissociates at the catalyst surface and combines with hydrogen ions [4,5]. Different factors can influence the reaction kinetics at the electrode surface, but still the electrocatalyst itself has the major effect. There are two pathways for the oxygen reduction reaction in aqueous electrolyte: four-electron and two-electron pathways. The direct four-electron pathway is preferable because the Faradaic efficiency of the reaction is greater; also it does not involve peroxide species in the solution.

To date, $\mathrm{Pt}$ and its alloys are the best known electrocatalysts for the ORR [6-9]. In order to reduce the cost of using pure $\mathrm{Pt}$ metal as a catalyst, alloying $\mathrm{Pt}$ with another metal reduces the cost; however the metal leaches away gradually $[9,10]$, resulting in the loss of performance that reduces the total fuel cell efficiency and limits their market use. The current fuel cell technology is based on the development of non-precious metals and Pt-free electrocatalysts [10]. Transition metal oxides are new materials that exhibit excellent activity in many applications because of their rich redox reactions, higher conductivity than simple oxides, and availability of active sites. Wang et al. [11] fabricated graphene-nickel cobaltite nanocomposite (GNCC) that was used as a positive electrode in supercapacitors application. Higher capacitance was obtained for GNCC (618 F.g $\left.{ }^{-1}\right)$ compared with graphene- $\mathrm{Co}_{3} \mathrm{O}_{4}\left(340 \mathrm{~F} \cdot \mathrm{g}^{-1}\right)$ or graphene- $\mathrm{NiO}\left(375 \mathrm{~F} \cdot \mathrm{g}^{-1}\right)$ due to the rich numbers of Faradaic reactions on the nickel cobaltite. Moreover, Genqiang Zhang et al. [12] synthesized $\mathrm{NiCo}_{2} \mathrm{O}_{4}-\mathrm{rGO}$ hybrid nanosheets electrocatalysts for the oxygen reduction reaction. He found a comparable current density and onset potential with those of commercial $\mathrm{Pt} / \mathrm{C}$ catalysts. In another study [13], cobalt ferrite thin films were prepared and tested as anode for lithium-ion batteries.

Carbon nanomaterials such as carbon nanotubes and graphene were applied as electrocatalysts for ORR application [14,15] and exhibited good performance due to their surface active sites that are necessary for reactants adsorption, bond-breaking and new bond-formation, and products desorption. A new emerging class of carbon nanomaterials is carbon gel [16,17], which has good electrochemical properties and high surface areas. Recently, carbon gels were tested as electrodes in methanol oxidation [18], supercapacitors [19], environmental applications [20,21], and oxygen reduction reaction (ORR) [22,23]. Carbon gels, in both of its forms xerogels and aerogels, offer the opportunity to be used as it is or doped with metals which enhances its electrochemical activity as the metal doping influences the obtained surface area and morphology [24-26].

To the best of our knowledge, bimetal oxides-doped carbon xerogels have not been tested before as electrocatalysts for oxygen reduction reaction in basic medium. So, in this work carbon xerogels were prepared by sol-gel process using two metal salts as polymerization catalysts namely cobalt acetate and nickel acetate to investigate the role of the metal catalyst. Moreover, the resultant two carbon xerogels were further doped with different binary metal oxides of nickel cobaltite, nickel ferrite, and cobalt ferrite through the hydrothermal method. The prepared samples were employed as electrocatalysts for oxygen reduction reaction, as this is one of our main goals to study the effect of bimetal oxides on the morphology of carbon gels and its activity toward ORR.

\section{Materials and Methods}

\subsection{Preparation of Carbon Xerogel}

The used monomers for preparation of carbon xerogels were resorcinol $(\mathrm{R})$ and formaldehyde $(\mathrm{F})$ with a molar ratio of $\mathrm{R} / \mathrm{F}=1 / 2$. These monomers were dissolved in water $(\mathrm{W})$ in the presence of cobalt acetate and nickel acetate as the polymerization catalysts. The amount of cobalt and nickel in the final carbon structure was calculated to be $6 \mathrm{wt} . \%$ and the used molar ratio between resorcinol and water $\mathrm{R} / \mathrm{W}$ was $1 / 17$. After stirring, the clear solution was filled in glass molds and placed in the oven for one day at $40{ }^{\circ} \mathrm{C}$ then five days at $80^{\circ} \mathrm{C}$. The obtained organic gel was placed in acetone for 3 days to allow solvent exchange to save the porosity during the drying method. The organic gels were dried using the microwave drying method (domestic Samsung microwave F600G, Samsung, MWF600G, Beijing, 
China) under Ar-gas flow at power of $10 \%$ for $10 \mathrm{~min}$ ) to get their corresponding organic xerogels, followed by the carbonization process in tube furnace (Carbolite Gero single zone EVA, Carbolite Gero Neuhausen, Germany) at $900{ }^{\circ} \mathrm{C}$ for $2 \mathrm{~h}$ with a heating rate of $1^{\circ} \mathrm{C} / \mathrm{min}$ to get the carbon xerogels.

\subsection{Binary Metal Oxides Surface Modification $\left(\mathrm{XY}_{2} \mathrm{O}_{4} / \mathrm{CX}\right)$}

The obtained cobalt and nickel-doped carbon xerogels were further doped with three different bimetal oxides through the hydrothermal process. Nickel cobaltite $\left(\mathrm{NiCO}_{2} \mathrm{O}_{4}\right)$, nickel ferrite $\left(\mathrm{NiFe}_{2} \mathrm{O}_{4}\right)$, cobalt ferrite $\left(\mathrm{CoFe}_{2} \mathrm{O}_{4}\right)$ were chosen to be used as the bimetal oxides for doping.

In the synthesis of $\mathrm{NiCo}_{2} \mathrm{O}_{4} / \mathrm{Co}-\mathrm{CX}$ and $\mathrm{NiCo}_{2} \mathrm{O}_{4} / \mathrm{Ni}-\mathrm{CX}$, typically $120 \mathrm{mg}$ of carbon xerogel was

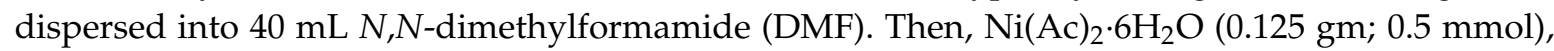
$\mathrm{Co}(\mathrm{Ac})_{2} \cdot 4 \mathrm{H}_{2} \mathrm{O}(0.250 \mathrm{gm} ; 1 \mathrm{mmol})$, and urea $(0.360 \mathrm{gm} ; 6 \mathrm{mmol})$ were dissolved in $30 \mathrm{~mL}$ solution of $\mathrm{H}_{2} \mathrm{O}$ and ethylene glycol with a volumetric ratio of 1:2. The two solutions were sonicated for $15 \mathrm{~min}$ and were placed in a polytetrafluoroethylene lined stainless steel autoclave at $180{ }^{\circ} \mathrm{C}$ for $12 \mathrm{~h}$. The black precipitate obtained after the hydrothermal reaction was collected by centrifugation ( $4000 \mathrm{rpm}$ for $5 \mathrm{~min}$ ), washed several times with water and ethanol, dried at $60^{\circ} \mathrm{C}$ for $12 \mathrm{~h}$, and finally calcined at $360^{\circ} \mathrm{C}$ for $3 \mathrm{~h}$ with a heating rate of $5^{\circ} \mathrm{C} / \mathrm{min}$.

The same procedure was followed for the preparation of nickel ferrite $\left(\mathrm{NiFe}_{2} \mathrm{O}_{4}\right)$ and cobalt ferrite $\left(\mathrm{CoFe}_{2} \mathrm{O}_{4}\right)$ doped carbon xerogel except with replacing the metal salts with the appropriate ones and maintaining the molar ratios between the two salts at 1:2.

\subsection{Characterization}

The prepared samples were fully characterized with different characterization techniques. Sample surface area and porosity were characterized using surface area analysis with $\mathrm{N}_{2}$ adsorption at $-196^{\circ} \mathrm{C}$ using the Quantachrome instrument (Quadrasorb, Boynton Beach, FL, USA) and then by applying the Brunauer-Emmett-Teller (BET) equation the isotherms were obtained. Before porosity analysis, the samples were outgassed for $12 \mathrm{~h}$ at $110^{\circ} \mathrm{C}$ under high vacuum of $10^{-6} \mathrm{mbar}$. The mesoporosity of the prepared materials were calculated by applying the density functional theory (DFT) equation to the adsorption part of $\mathrm{N}_{2}$-isotherms. Moreover, the samples morphology and particle size distribution were analyzed using scanning electron microscopy (SEM) and high resolution transmission electron microscopy (HRTEM), respectively. SEM analysis was performed using Zeiss SUPRA40VP instrument (Carl Zeiss AG, Oberkochen, Germany), equipped with both SE and BSE detectors and X-Max $50 \mathrm{~mm}$ energy dispersive $\mathrm{X}$-ray microanalysis system.

HRTEM was carried out with FEI Titan G2 60-300 microscope (FEI, Eindhoven, Netherlands) with a high brightness electron gun (X-FEG) operated at $300 \mathrm{KV}$ and equipped with a Cs image corrector (CEOS) and analytical electron microscopy (AEM) with a SUPER-X silicon-drift window-less EDX detector.

XRD analysis was carried out with a BRUKER D8 DISCOVER diffractometer (BRUKER, Rivas-Vaciamadrid, Spain) equipped with a $\mathrm{I} \mu \mathrm{S} \mathrm{Cu}$ microsource, operating at $50 \mathrm{KV}, 1 \mathrm{~mA}$, and $50 \mathrm{~W}$ at $25^{\circ} \mathrm{C}$, using a Cu K $\alpha(\lambda=15,406 \AA)$ radiation, a Multilayer Optics Monochromator (Quazar Optics: Montel type 2-dim beam shaping) (Incoatec, Geesthacht, Germany), and a PILATUS3R 100K-A detector (Dectris Ltd, Baden, Switzerland). Diffraction patterns were recorded between $10^{\circ}$ and $80^{\circ}$

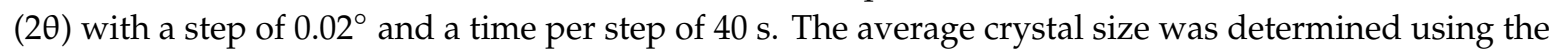
Scherrer equation.

X-ray photoelectron spectroscopy (XPS) measurements were carried out with a physical electronics ESCA 5701 (PHI, Chanhassen, MN, USA) operating at $12 \mathrm{KV}$ and $10 \mathrm{~mA}$ and equipped with a MgK $\mathrm{X}$-ray source $(h v=1253.6 \mathrm{eV})$. The obtained binding energy values are referred to C1s, O1s, and N1s peaks at 284.6, 529.3, and 399.3, respectively. 


\subsection{Electrode Preparation for ORR}

A total of $5 \mathrm{mg}$ of the prepared carbon material was dispersed into $400 \mu \mathrm{L}$ of isopropanol and $30 \mu \mathrm{L}$ of nafion solution ( $5 \mathrm{wt} . \%$ ), and then sonicated (sonication bath, Samarth electronics, for $15 \mathrm{~min}$ ). Ten microliter of the suspended solution was deposited into a glassy carbon electrode with a diameter of $3 \mathrm{~mm}$ and dried under an infrared lamp for $5 \mathrm{~min}$ (100 W, R95, Philips, Madrid, Spain).

\subsection{Electrochemical Measurements}

The electrochemical measurements were carried out using a biologic multichannel VMP3 potentiostat (BioLogic, Seyssinet-Pariset, France). A three-electrode electrochemical cell was used during the analysis of electrodes performance in which $\mathrm{Ag} / \mathrm{AgCl}$ and $\mathrm{Pt}$ electrodes were used as reference and counter electrodes, respectively. The used electrolyte was $0.1 \mathrm{M}$ potassium hydroxide $(\mathrm{KOH})$, which is first saturated with nitrogen then saturated with $\mathrm{O}_{2}$ to evaluate the electrocatalyst performance in the absence and presence of oxygen. Different electrochemical techniques were used in the electrode evaluation: (i) cyclic voltammetry (CV), (ii) linear sweep voltammetry (LSV), and (iii) electrochemical impedance spectroscopy (EIS).

The cyclic voltammetry and linear sweep voltammetry were carried out in a potential range between 0.4 to $-0.8 \mathrm{~V}$. Two scan rates of $5 \mathrm{mV} \cdot \mathrm{s}^{-1}$ and $50 \mathrm{mV} \cdot \mathrm{s}^{-1}$ were used with $\mathrm{CV}$ and different rotation speeds from 500 to $4000 \mathrm{rpm}$ were employed for LSV at $5 \mathrm{mV} \cdot \mathrm{s}^{-1}$ in order to be able to apply the Koutecky-Levich model for evaluating the electrocatalyst performance and calculating the number of transferred electrons.

$$
\begin{gathered}
\frac{1}{j}=\frac{1}{j_{k}}+\frac{1}{B \omega^{0.5}} \\
B=0.2 n F\left(D_{\mathrm{O}_{2}}\right)^{2 / 3} v^{-1 / 6} C_{\mathrm{O}_{2}}
\end{gathered}
$$

where $j$, current density; $j_{k}$, kinetic current density; $\omega$, rotation speed; $F$, Faraday constant; $D_{O 2}$, oxygen diffusion coefficient $\left(1.9 \cdot 10^{-5} \mathrm{~cm}^{2} \cdot \mathrm{s}^{-1}\right) ; v$, viscosity $\left(0.01 \mathrm{~cm}^{2} \cdot \mathrm{s}^{-1}\right) ; C_{O 2}$, oxygen concentration $\left(1.2 \cdot 10^{-6} \mathrm{~mol} \cdot \mathrm{cm}^{-3}\right)$.

\section{Results}

Table 1 is constructed by applying the BET equation for the obtained isotherms of $\mathrm{N}_{2}$ adsorption at $77 \mathrm{~K}$. The BET surface areas $\left(\mathrm{S}_{\mathrm{BET}}\right)$ ranged between 50 to $156 \mathrm{~m}^{2} \cdot \mathrm{g}^{-1}$, as can be seen in Table 1 . The highest surface areas were obtained for the samples doped with nickel ferrite $\mathrm{NiFe}_{2} \mathrm{O}_{4}$, which means these samples have high microporosity as appears from their pore size (Lo) data.

Table 1. Surface area analysis.

\begin{tabular}{ccccccccc}
\hline \multirow{2}{*}{ Sample } & $\mathbf{S}_{\text {BET }}$ & $\mathbf{W}_{\mathbf{0}}\left(\mathbf{N}_{\mathbf{2}}\right)$ & $\mathbf{L}_{\mathbf{0}}\left(\mathbf{N}_{\mathbf{2}}\right)$ & $\mathbf{V}_{\mathbf{0 . 9 5}}\left(\mathbf{N}_{\mathbf{2}}\right)$ & $\mathbf{V}_{\text {meso }}\left(\mathbf{N}_{\mathbf{2}}\right)$ & $\mathbf{S}_{\text {DFT }}$ & $\mathbf{V}_{\text {DFT }}$ & $\mathbf{L}_{\mathbf{0}}$ (DFT) \\
\cline { 2 - 9 } & $\mathbf{m}^{\mathbf{2}} / \mathbf{g}$ & $\mathbf{c m}^{\mathbf{3}} / \mathbf{g}$ & $\mathbf{n m}$ & $\mathbf{c m}^{\mathbf{3}} / \mathbf{g}$ & $\mathbf{c m}^{\mathbf{3}} / \mathbf{g}$ & $\mathbf{m}^{\mathbf{2}} / \mathbf{g}$ & $\mathbf{c m}^{\mathbf{3}} / \mathbf{g}$ & $\mathbf{n m}$ \\
\hline $\mathrm{NiFe}_{2} \mathrm{O}_{4} / \mathrm{Ni}-\mathrm{CX}$ & 156 & 0.06 & 1.91 & 0.46 & 0.40 & 185 & 0.47 & 2.18 \\
$\mathrm{NiCo}_{2} \mathrm{O}_{4} / \mathrm{Ni}-\mathrm{CX}$ & 57 & 0.02 & 2.20 & 0.27 & 0.24 & 103 & 0.31 & 2.60 \\
$\mathrm{CoFe}_{2} \mathrm{O}_{4} / \mathrm{Ni}-\mathrm{CX}$ & 84 & 0.03 & 1.98 & 0.35 & 0.31 & 127 & 0.36 & 2.84 \\
$\mathrm{NiFe}_{2} \mathrm{O}_{4} / \mathrm{Co}-\mathrm{CX}$ & 112 & 0.04 & 1.77 & 0.33 & 0.29 & 139 & 0.37 & 2.84 \\
$\mathrm{NiCo}_{2} \mathrm{O}_{4} / \mathrm{Co}-\mathrm{CX}$ & 64 & 0.03 & 2.98 & 0.30 & 0.27 & 128 & 0.32 & 2.84 \\
$\mathrm{CoFe}_{2} \mathrm{O}_{4} / \mathrm{Co}-\mathrm{CX}$ & 50 & 0.02 & 1.48 & 0.27 & 0.25 & 85 & 0.29 & 2.18 \\
\hline
\end{tabular}

$\mathrm{W}_{0}$ is the micropore volume, $\mathrm{L}_{0}$ is the pore size, $\mathrm{V}_{0.95}$ is the pore volume at relative pressure of $0.95, \mathrm{~V}_{\text {meso }}$ is the mesopore volume. $\mathrm{S}_{\mathrm{DFT}}, \mathrm{V}_{\mathrm{DFT}}$, and $\mathrm{L}_{0}(\mathrm{DFT})$ are the surface area, pore volume, and pore size obtained from $\mathrm{DFT}$ calculations, respectively.

Doping of carbon xerogel with bimetal oxides promote mesoporosity of carbon structure and this mesoporosity is confirmed by applying the DFT equation to the adsorption part for the obtained $\mathrm{N}_{2}$ - isotherms (Figure 1). The DFT pores diameters $\left(\mathrm{L}_{\mathrm{o}}(\mathrm{DFT})\right.$ ) ranged from 2.18-2.84 nm and the samples doped with nickel cobaltite, $\mathrm{NiCo}_{2} \mathrm{O}_{4}$, showed homogenous particle size distribution. The mesoporous character of these samples is confirmed by the type-IV shape of their corresponding 
adsorption-desorption isotherms (Figure S1 in Supplementary Materials), also showing all of their significant hysteresis cycles.
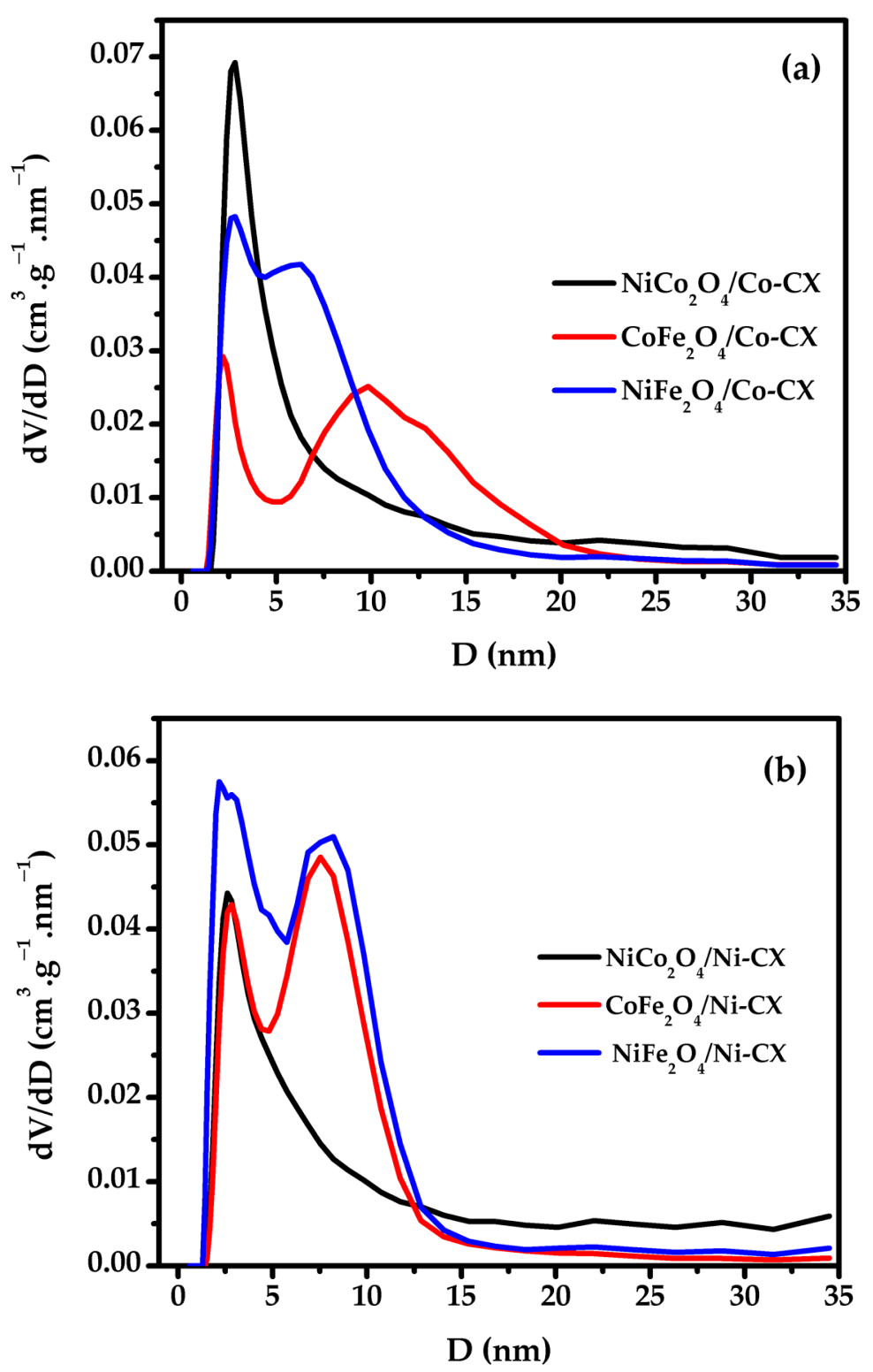

Figure 1. DFT analysis for adsorption part of $\mathrm{N}_{2}$-adsorption/desorption isotherms, (a) bimetal oxides doped cobalt xerogels, (b) bimetal oxides doped nickel xerogels.

The existence of the binary metal oxides inside the carbon matrix is confirmed by XRD analysis (Figure 2) in which the crystallinity of the bimetal oxides is confirmed by the XRD pattern with the absence of any contaminated peaks. The XRD pattern of nickel cobaltite doped carbon xerogels and their corresponding planes is presented in Figure 2c.

The morphology of the prepared samples is revealed from the SEM images (Figure 3). The carbon xerogel undergoes morphology transformation from continued connected spherical particles to nano-needle like structure when doped with nickel cobaltite (Figure $3 a, b)$, while it maintains its original morphology when doped with nickel ferrite (Figure 3c,d) or cobalt ferrite (Figure 3e,f).

The homogeneity and dispersity of the doped bimetal oxides nanoparticles inside the carbon matrix is studied from the TEM images (Figure 4). The metal nanoparticles are well dispersed inside the carbon structure in case of the doped samples with nickel ferrite (Figure 4c,d) and cobalt ferrite (Figure 4e,f). In addition, the nano-needle structure for nickel cobaltite with different lengths and 
widths was formed in both cobalt-doped carbon xerogels (Co-CX, Figure 4a) and nickel-doped carbon xerogels (Ni-CX, Figure 4b) [18].

Figure 5 shows the XP spectra of the prepared electrocatalysts in the presence of the metal cations in divalent and trivalent oxidation states. The prepared electrodes were tested as electrocatalysts for ORR application and their cyclic voltammograms for nickel cobaltite doped ones are presented in Figure 6.

The linear sweep voltammetry (LSV) technique is used with rotating desk electrode (Figure 7), and the electrocatalytic activity at different rotation speed is shown in Figure 8. The data obtained from LSV were used in order to apply the Koutecky-Levich model for the determination of the number of electrons transferred (Figure 9).
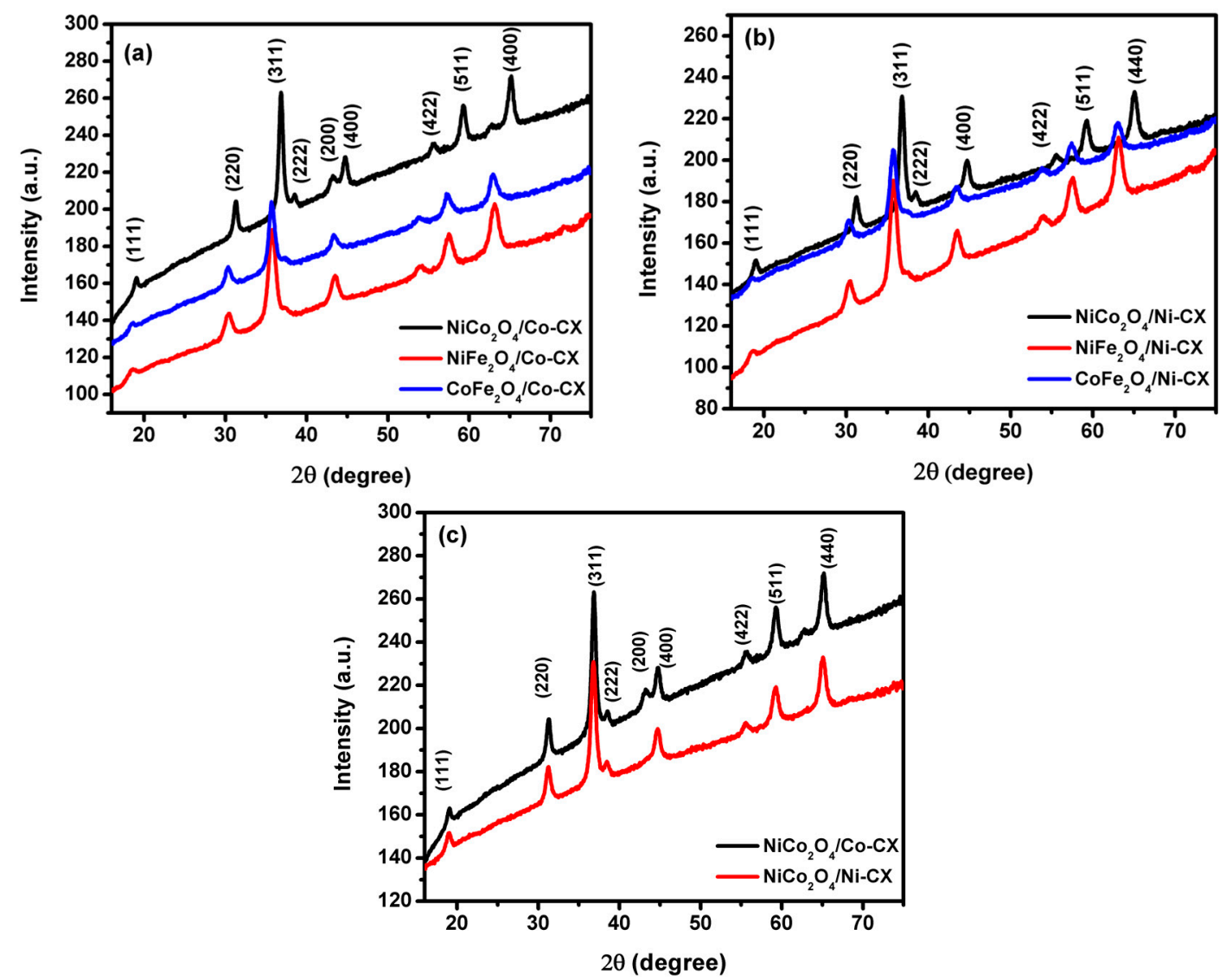

Figure 2. The XRD patterns for (a) bimetal oxides doped cobalt xerogels, (b) bimetal oxides doped nickel xerogels and (c) nickel cobaltite doped cobalt and nickel carbon xerogels. 


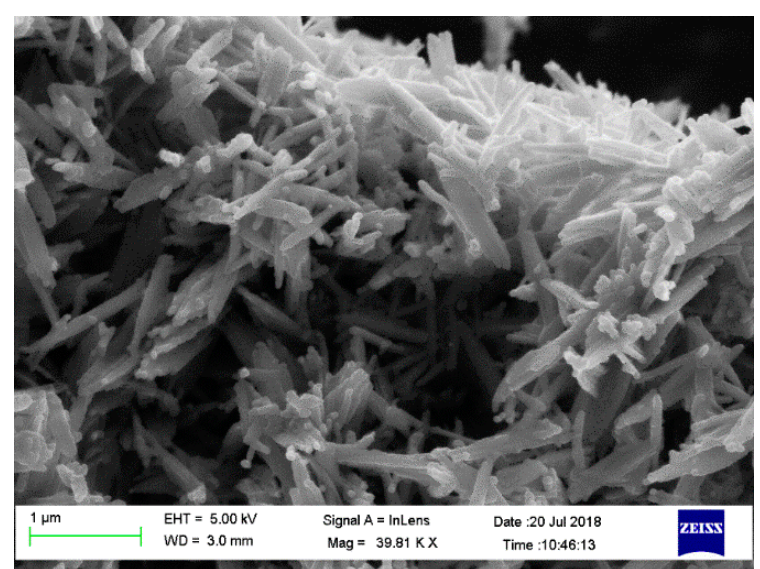

(a)

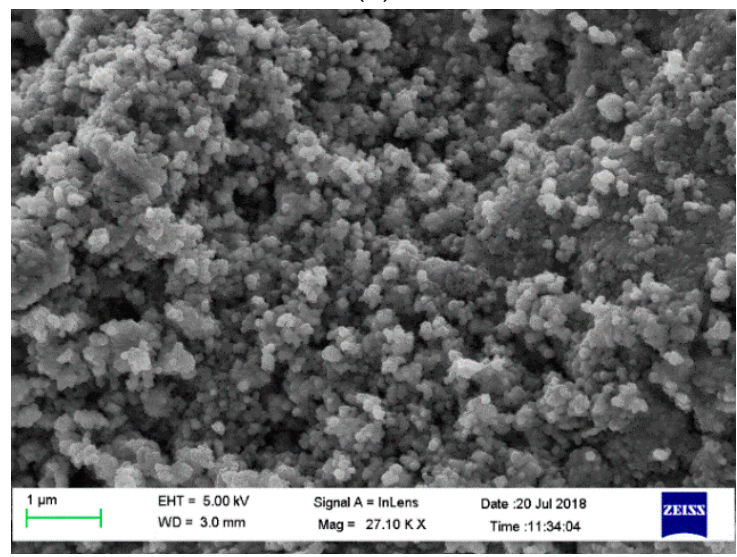

(c)

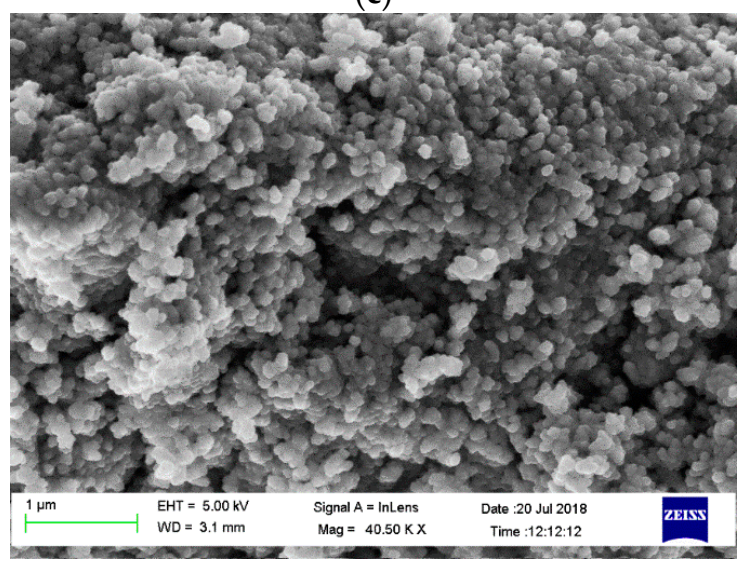

(e)

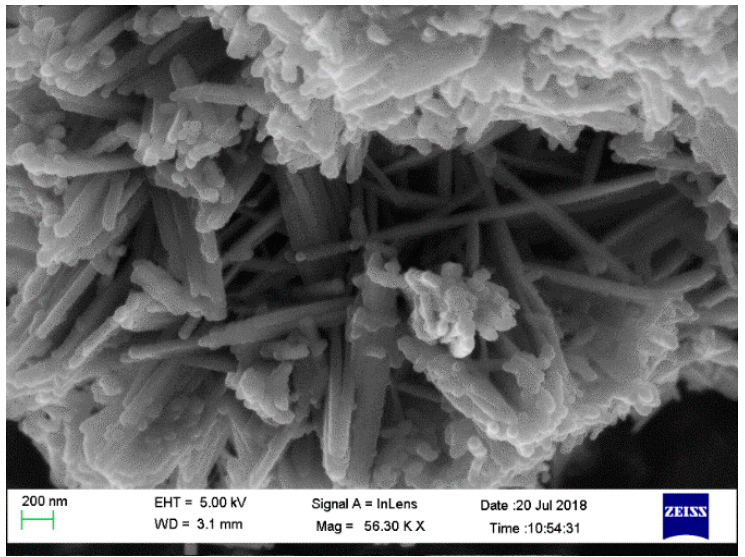

(b)

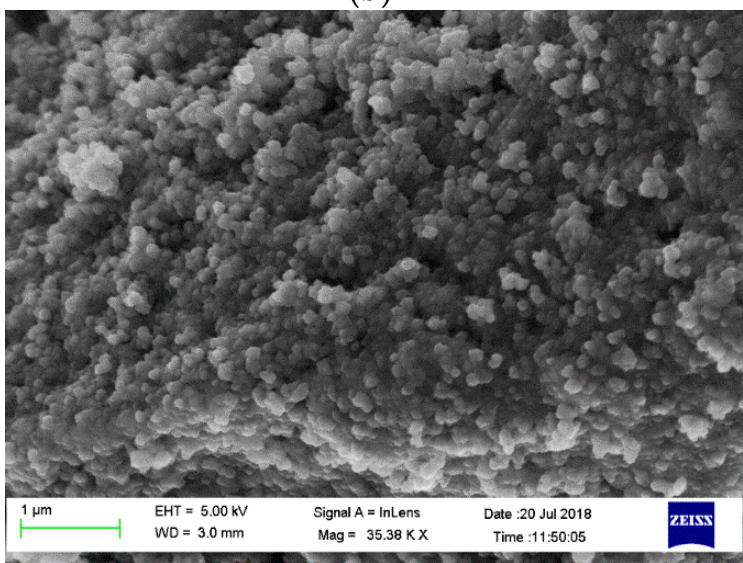

(d)

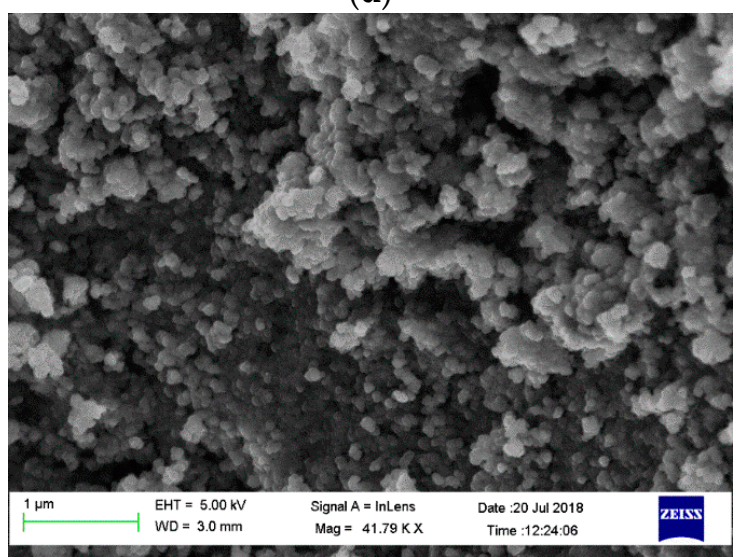

$(\mathbf{f})$

Figure 3. Scanning electron microscopy (SEM) images for (a) $\mathrm{NiCo}_{2} \mathrm{O}_{4} / \mathrm{Co}-\mathrm{CX}$, (b) $\mathrm{NiCo}_{2} \mathrm{O}_{4} / \mathrm{Ni}-\mathrm{CX}$, (c) $\mathrm{NiFe}_{2} \mathrm{O}_{4} / \mathrm{Co}-\mathrm{CX}$, (d) $\mathrm{NiFe}_{2} \mathrm{O}_{4} / \mathrm{Ni}-\mathrm{CX}$, (e) $\mathrm{CoFe}_{2} \mathrm{O}_{4} / \mathrm{Co}-\mathrm{CX}$, and (f) $\mathrm{CoFe}_{2} \mathrm{O}_{4} / \mathrm{Ni}-\mathrm{CX}$. 


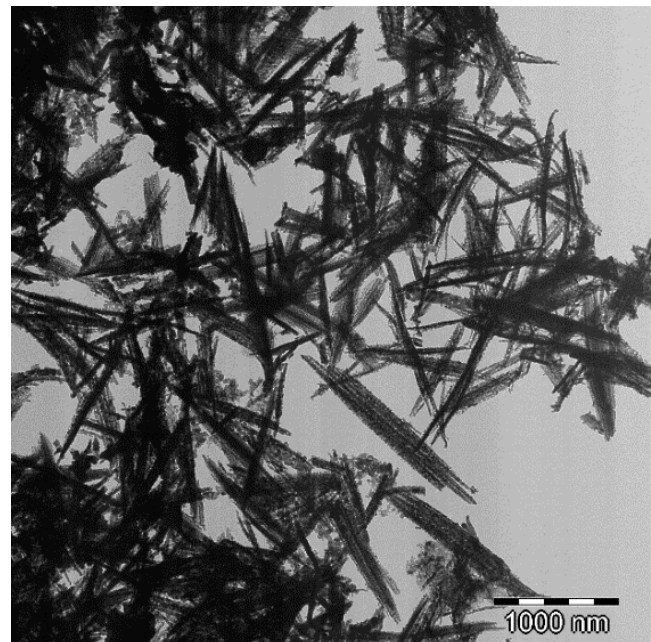

(a)

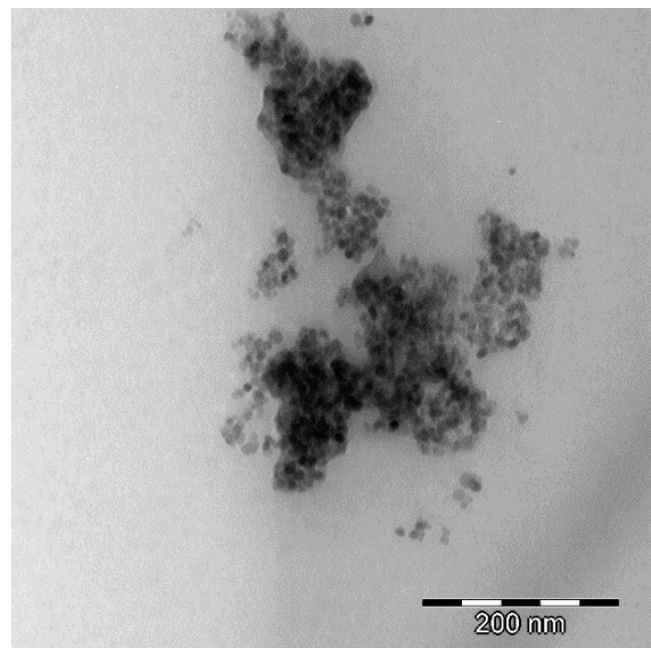

(c)

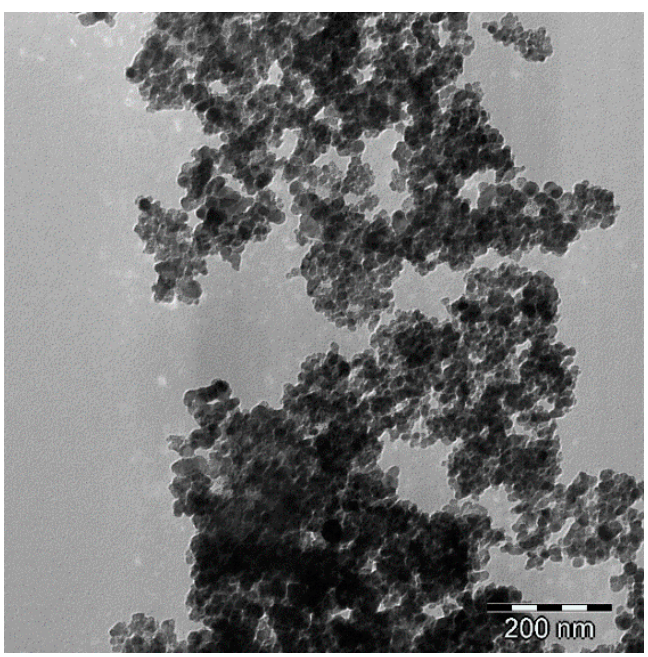

(e)

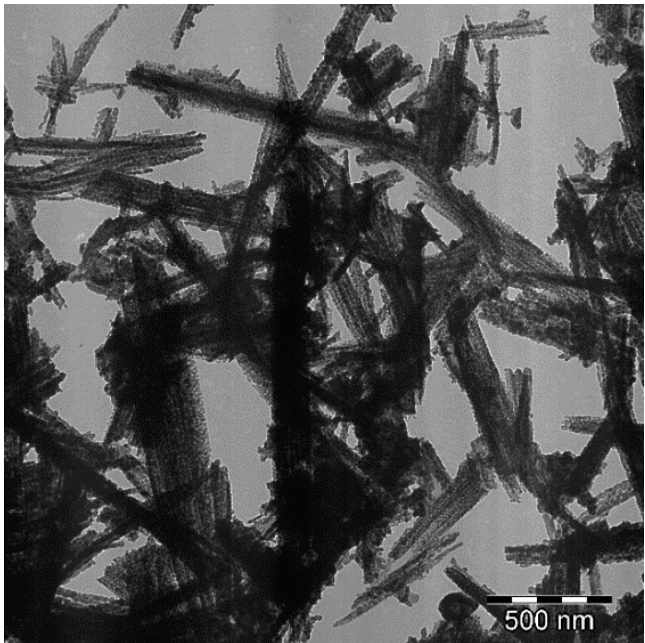

(b)

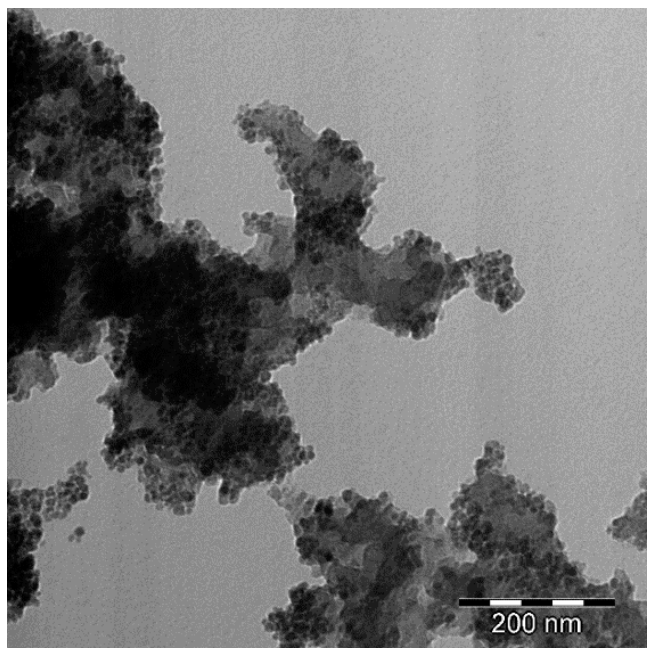

(d)

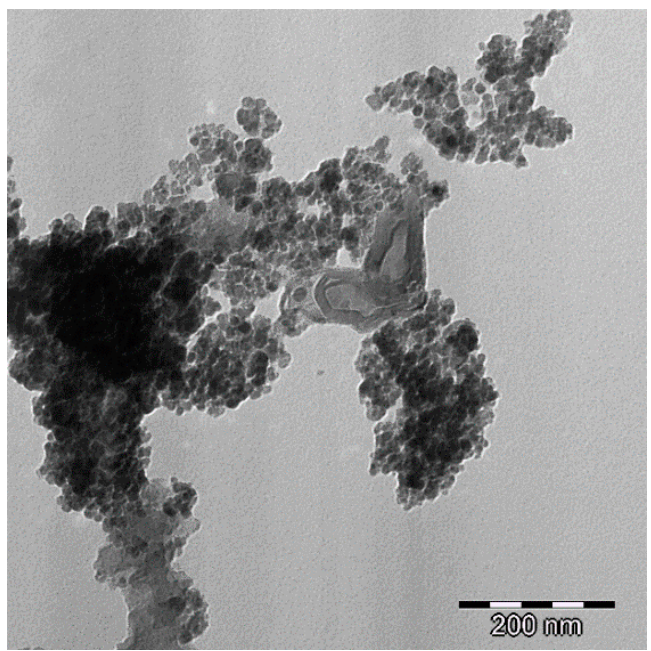

(f)

Figure 4. High resolution transmission electron microscopy (HRTEM) images for (a) $\mathrm{NiCo}_{2} \mathrm{O}_{4} / \mathrm{Co}-\mathrm{CX}$, (b) $\mathrm{NiCo}_{2} \mathrm{O}_{4} / \mathrm{Ni}-\mathrm{CX}$, (c) $\mathrm{NiFe}_{2} \mathrm{O}_{4} / \mathrm{Co}-\mathrm{CX}$, (d) $\mathrm{NiFe}_{2} \mathrm{O}_{4} / \mathrm{Ni}-\mathrm{CX}$, (e) $\mathrm{CoFe}_{2} \mathrm{O}_{4} / \mathrm{Co}-\mathrm{CX}$, and (f) $\mathrm{CoFe}_{2} \mathrm{O}_{4} / \mathrm{Ni}-\mathrm{CX}$. 


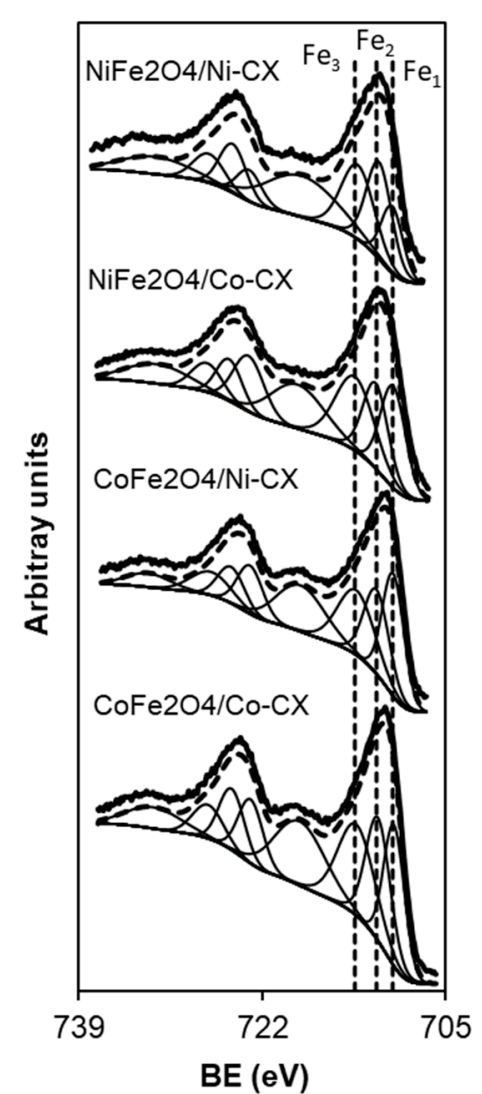

(a)

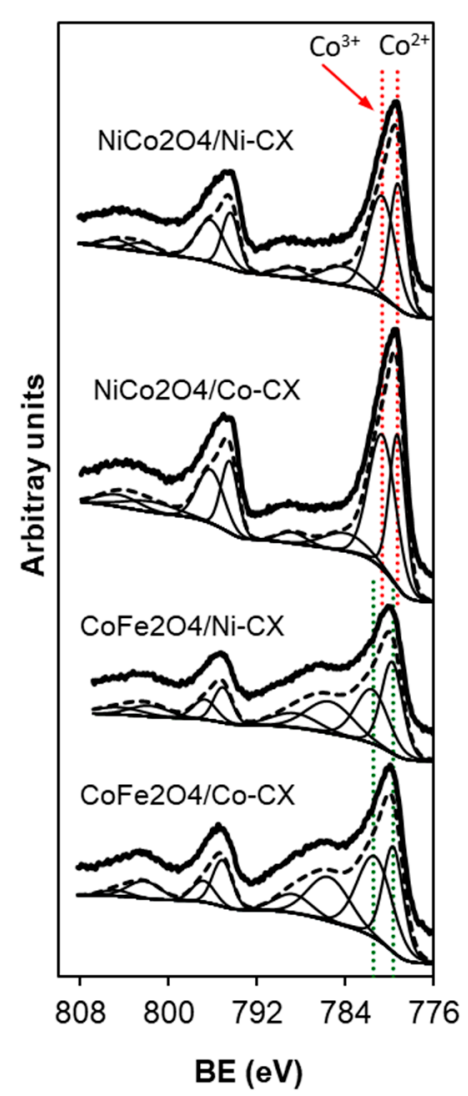

(b)

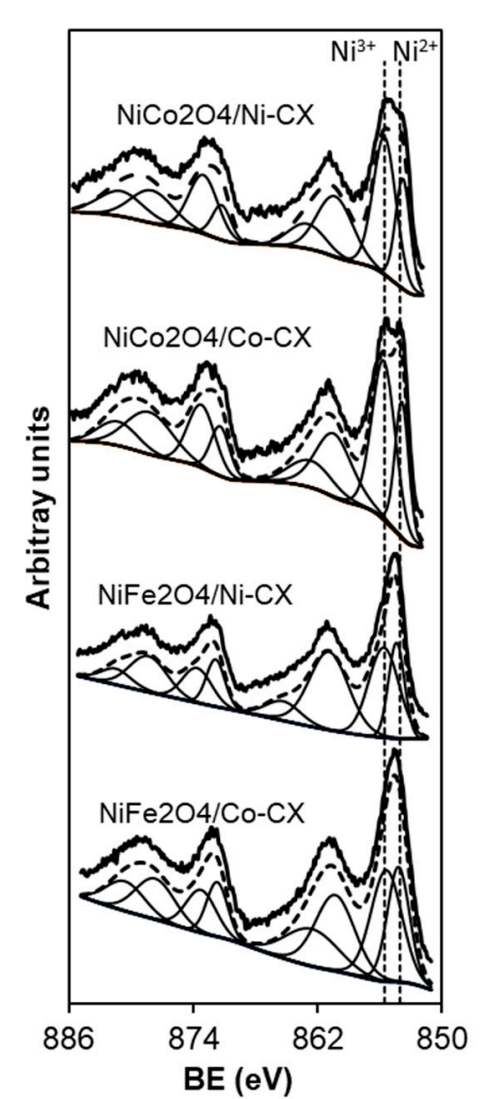

(c)

Figure 5. Deconvolution of the XP spectra for the prepared materials. (a) $\mathrm{NiFe}_{2} \mathrm{O}_{4}$ and $\mathrm{CoFe}_{2} \mathrm{O}_{4}$ doped carbon xerogels, (b) $\mathrm{NiCo}_{2} \mathrm{O}_{4}$ and $\mathrm{CoFe}_{2} \mathrm{O}_{4}$ doped carbon xerogels and (c) $\mathrm{NiCo}_{2} \mathrm{O}_{4}$ and $\mathrm{NiFe}_{2} \mathrm{O}_{4}$ doped carbon xerogels.
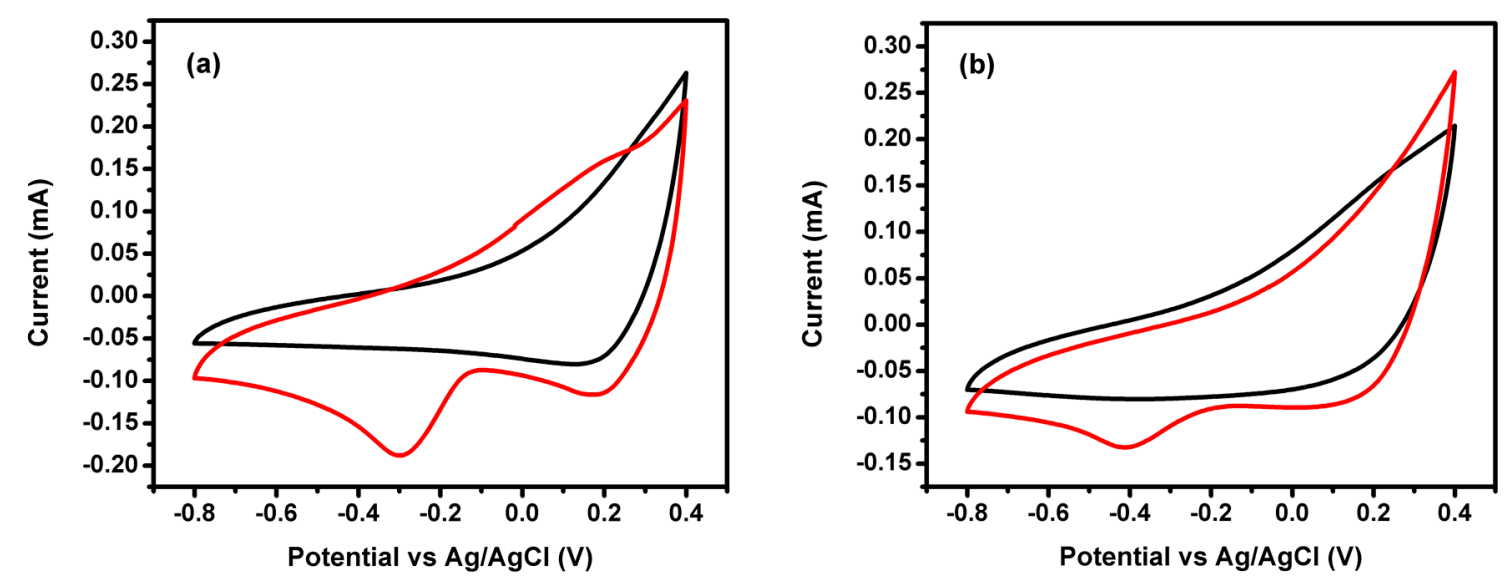

Figure 6. Cyclic voltammograms (CV) of (a) $\mathrm{NiCo}_{2} \mathrm{O}_{4} / \mathrm{Co}-\mathrm{CX}$ in both nitrogen (black) and oxygen (red) saturated electrolyte and (b) $\mathrm{NiCO}_{2} \mathrm{O}_{4} / \mathrm{Ni}-\mathrm{CX}$ in both nitrogen (black) and oxygen (red) saturated electrolyte. 

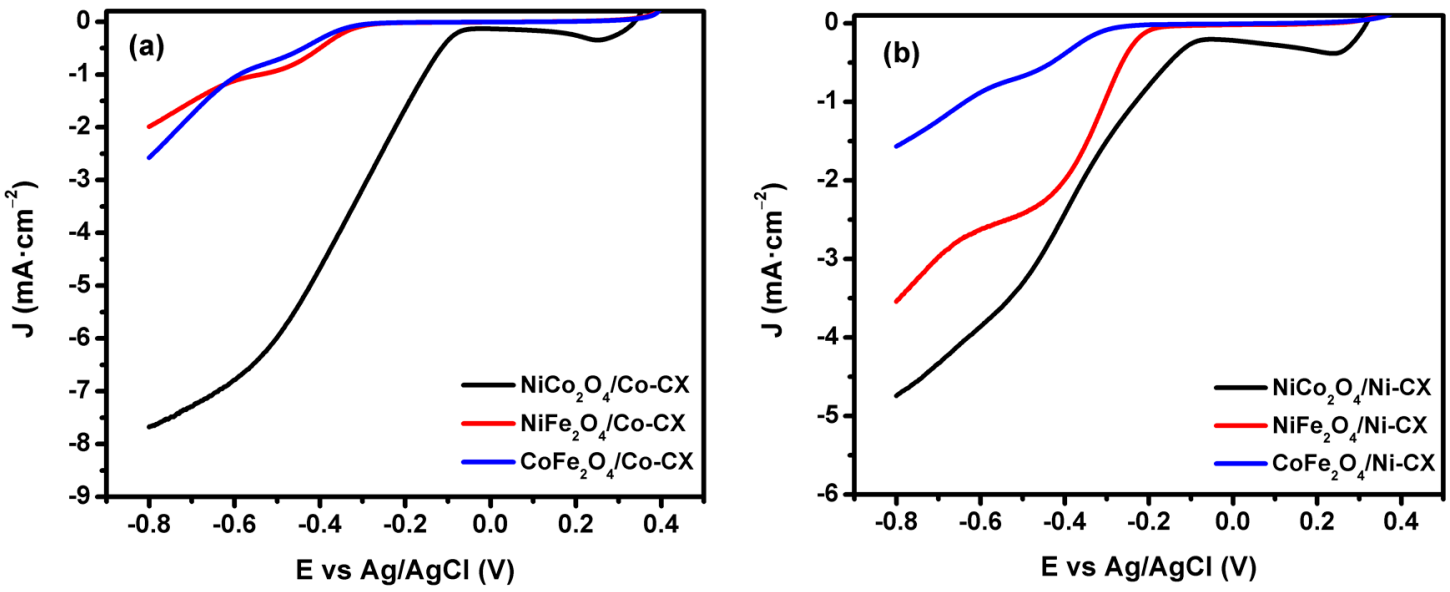

Figure 7. Linear sweep voltammograms (LSV) for (a) Co-CX and (b) Ni-CX doped with different bimetal oxides.
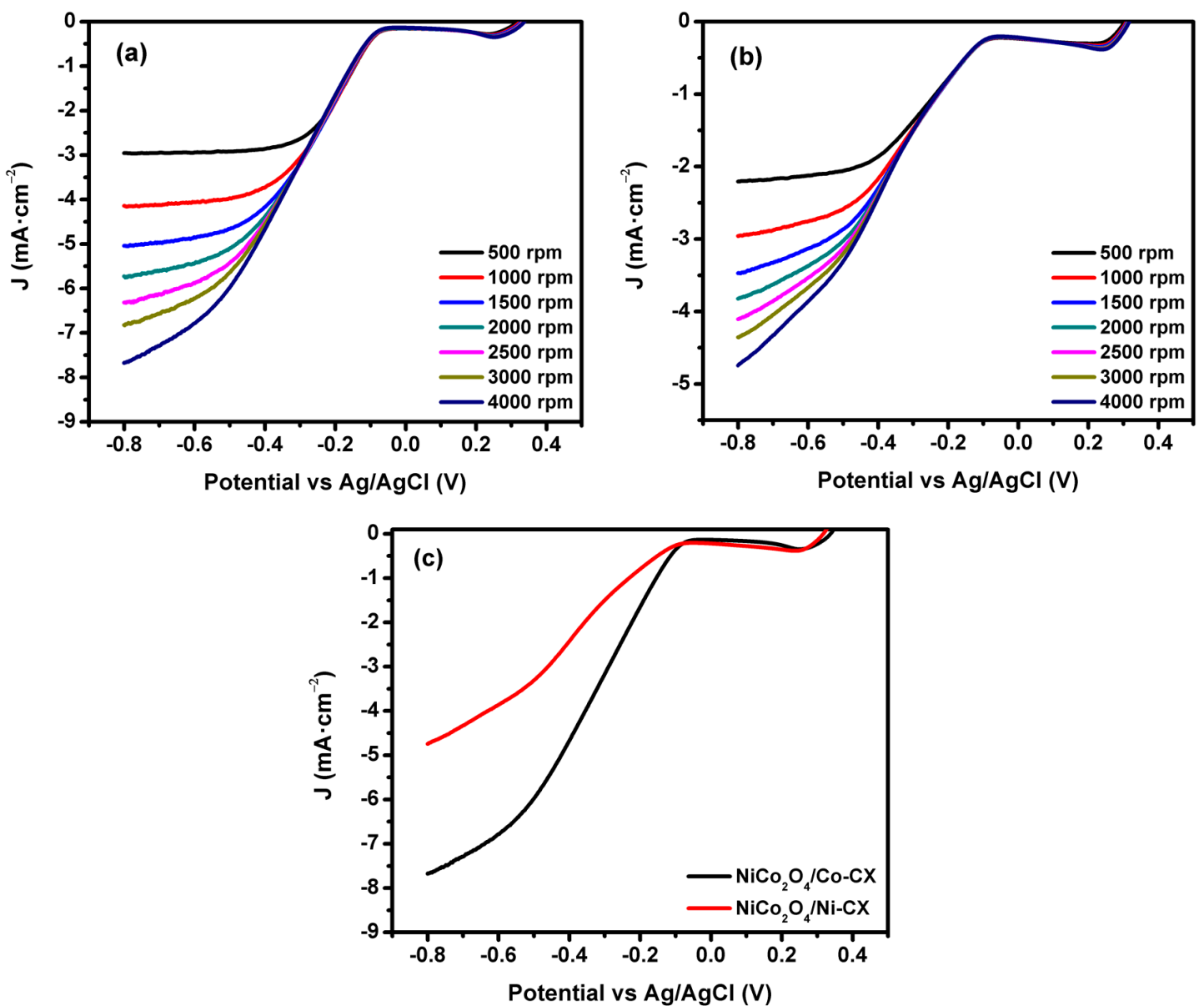

Figure 8. Linear sweep voltammograms (LSV) for (a) $\mathrm{NiCo}_{2} \mathrm{O}_{4} / \mathrm{Co}-\mathrm{CX}$, (b) $\mathrm{NiCo}_{2} \mathrm{O}_{4} / \mathrm{Ni}-\mathrm{CX}$ at $5 \mathrm{mV} \cdot \mathrm{s}^{-1}$ with different speeds from $500 \mathrm{rpm}$ to $4000 \mathrm{rpm}$ and (c) comparing the LSV for $\mathrm{NiCo}_{2} \mathrm{O}_{4} / \mathrm{Co}-\mathrm{CX}$ and $\mathrm{NiCo}_{2} \mathrm{O}_{4} / \mathrm{Ni}-\mathrm{CX}$ at $4000 \mathrm{rpm}$.

Electrochemical impedance spectroscopy (EIS) is an important technique for the evaluation of the performance of an electrode in certain applications by calculating the electrode resistance and equivalent series resistance (ESR). The EIS was performed by applying a frequency range from $100 \mathrm{KHz}$ to $1 \mathrm{mHz}$ with a sinusoidal signal amplitude of $10 \mathrm{mV}$, and the data obtained from EIS is shown in Figure 10. 

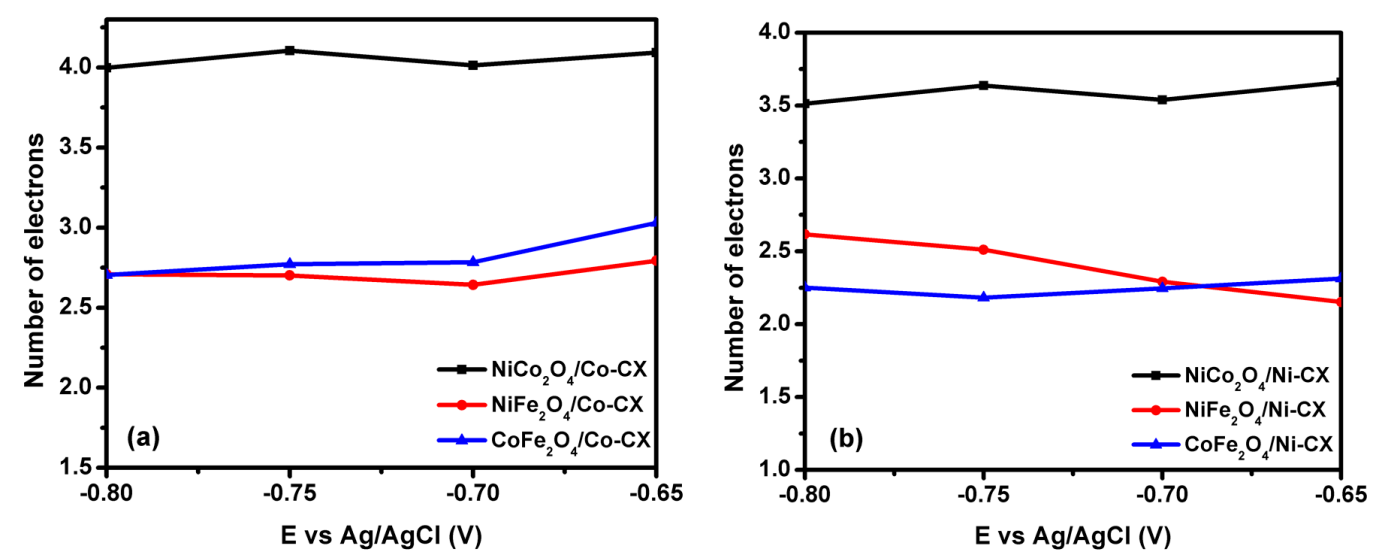

Figure 9. Variation of number of electron transferred with $\mathrm{E} v \mathrm{vs} . \mathrm{Ag} / \mathrm{AgCl}$ for bimetal oxides doped (a) Co-CX and (b) Ni-CX.
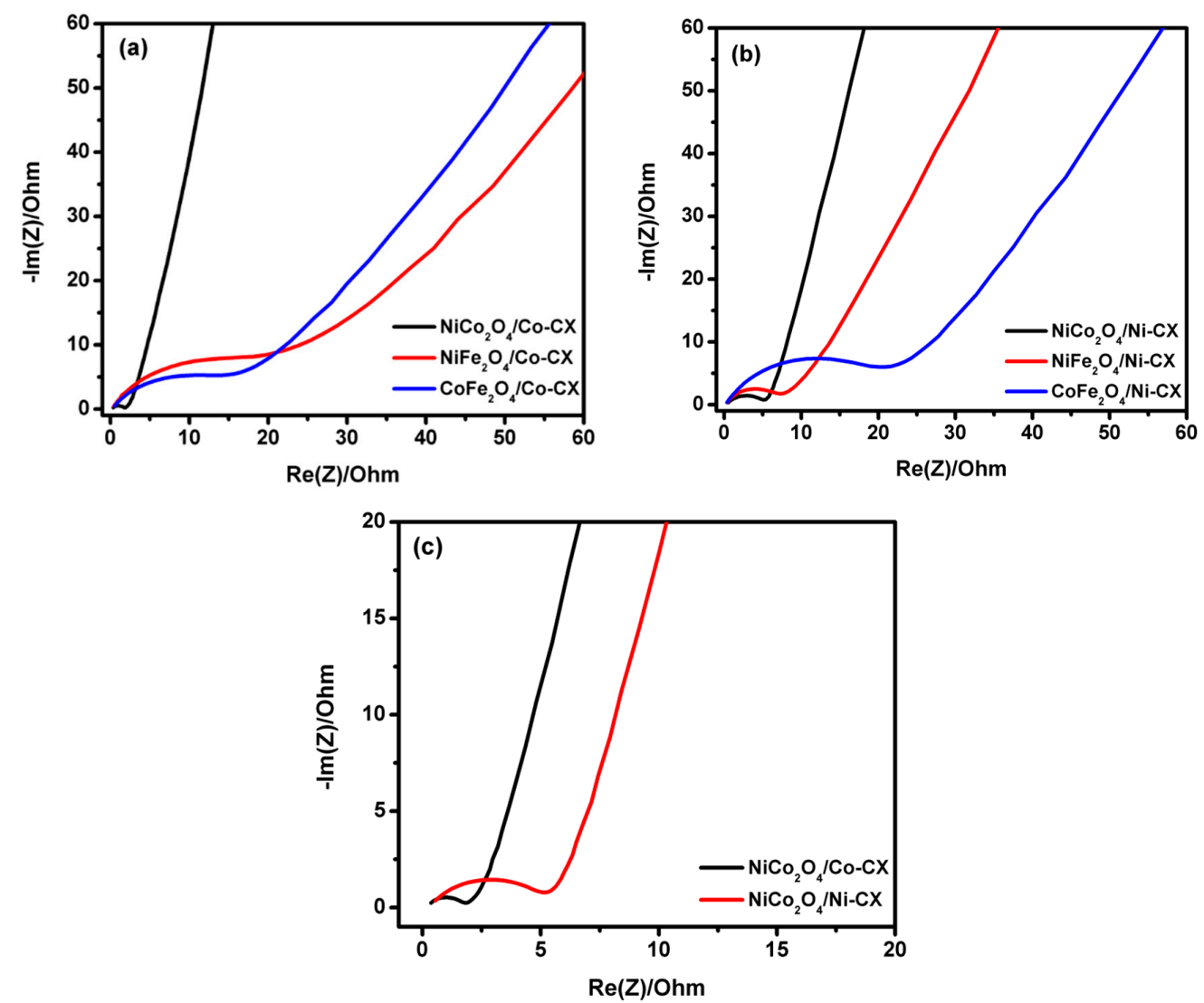

Figure 10. Nyquist plots obtained from EIS for bimetal oxides doped (a) Co-CX, (b) Ni-CX and (c) nickel cobaltite doped cobalt and nickel carbon xerogels.

\section{Discussion}

Samples doped with nickel cobaltite have well developed mesoporosity and in case of $\mathrm{NiCo}_{2} \mathrm{O}_{4} / \mathrm{Co}-\mathrm{CX}$ the mean pore size is $2.98 \mathrm{~nm}$, while for $\mathrm{NiCo}_{2} \mathrm{O}_{4} / \mathrm{Ni}-\mathrm{CX}$ is $2.20 \mathrm{~nm}$. The mesoporosity development is an indication for better accessibility of electrolyte ions inside the carbon structure, which in turn make these materials good electrocatalysts in catalysis application [27-29].

Energy-dispersive $\mathrm{X}$-ray spectroscopy (EDXS) analysis also confirmed the presence of the different metals in the samples. Figure $\mathrm{S} 2$ contains the analysis carried out on the sample $\mathrm{NiCo}_{2} \mathrm{O}_{4}-\mathrm{CoCX}$, as an example. 
Determination of mean particle sizes for the prepared samples was carried out by applying Scherrer equation for the obtained XRD patterns (Table 2). Higher particle sizes were obtained for the nickel cobaltite doped carbon xerogels. The higher mean particle sizes for nickel cobaltite doped samples indicates higher active sites in these samples which promote the electrocatalytic reduction of oxygen. For example, in $\mathrm{NiCo}_{2} \mathrm{O}_{4} / \mathrm{Co}-\mathrm{CX}$ the mean particle size is about $25.5 \mathrm{~nm}$ while for $\mathrm{NiFe}_{2} \mathrm{O}_{4} / \mathrm{Co}-\mathrm{CX}$ and $\mathrm{CoFe}_{2} \mathrm{O}_{4} / \mathrm{Co}-\mathrm{CX}$ is 19.8 and $21.8 \mathrm{~nm}$, respectively. Likewise for $\mathrm{Ni}-\mathrm{CX}$ series the $\mathrm{NiCo}_{2} \mathrm{O}_{4} / \mathrm{Ni}-\mathrm{CX}$ has the highest particle size of $24.1 \mathrm{~nm}$.

Table 2. Mean particle size obtained from Scherrer equation.

\begin{tabular}{cc}
\hline Sample & $\boldsymbol{d}_{\text {XRD }}(\mathbf{n m})$ \\
\hline $\mathrm{NiCo}_{2} \mathrm{O}_{4} / \mathrm{Co}-\mathrm{CX}$ & 25.5 \\
$\mathrm{NiFe}_{2} \mathrm{O}_{4} / \mathrm{Co}-\mathrm{CX}$ & 19.8 \\
$\mathrm{CoFe}_{2} \mathrm{O}_{4} / \mathrm{Co}-\mathrm{CX}$ & 21.8 \\
$\mathrm{NiCo}_{2} \mathrm{O}_{4} / \mathrm{Ni}-\mathrm{CX}$ & 24.1 \\
$\mathrm{NiFe}_{2} \mathrm{O}_{4} / \mathrm{Ni}-\mathrm{CX}$ & 21.1 \\
$\mathrm{CoFe}_{2} \mathrm{O}_{4} / \mathrm{Ni}-\mathrm{CX}$ & 20.2 \\
\hline
\end{tabular}

Table 3 collects the binding energies (B.E.) and chemical composition corresponding to carbon, oxygen, and nitrogen with respect to the chemical composition analysed by XPS. The oxygen peak at lowest B.E. $529.8 \pm 0.3 \mathrm{eV}$ corresponds to the oxygen atoms bond to transition metal cations with oxidation states +2 and +3 .

On the other hand, the XPS results corresponding to the region Fe2p are collected in Table 4 and Figure 5. Fe2 $\mathrm{p}_{3 / 2}$ peaks centred at $709.9 \pm 0.2,711.2 \pm 0.3$, and $713.2 \pm 0.2 \mathrm{eV}$ have been assigned to $\mathrm{Fe}^{2+}$ situated in octahedral holes $\left(\mathrm{Fe}_{1}\right), \mathrm{Fe}^{3+}$ situated in octahedral holes $\left(\mathrm{Fe}_{2}\right)$, and $\mathrm{Fe}^{3+}$ situated in tetrahedral holes $\left(\mathrm{Fe}_{3}\right)$, respectively. This means that iron is forming part of compounds type $\mathrm{M}_{\mathrm{x}}^{2+} \mathrm{M}_{1-\mathrm{x}}^{3+}\left[\mathrm{Fe}_{\mathrm{y}}^{2+} \mathrm{Fe}_{1-\mathrm{y}}^{3+}\right] \mathrm{O}_{4}[30]$ being $\mathrm{M}=\mathrm{Co}$ and/or Ni.

Table 3. Binding energies and chemical composition of C1s, O1s, and N1s.

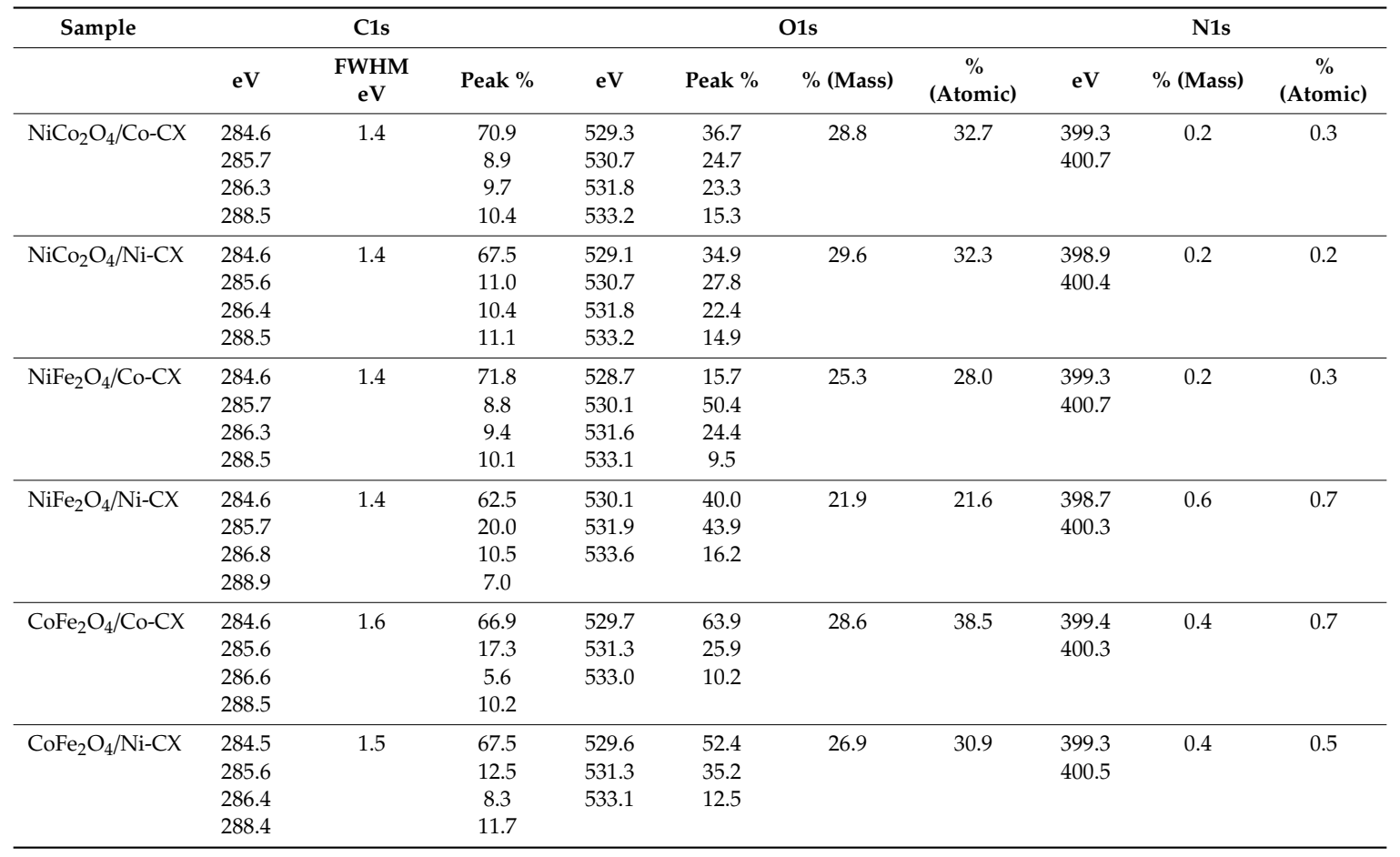


Table 4. XPS results collected after deconvolution of Peaks.

\begin{tabular}{|c|c|c|c|c|c|c|c|c|c|c|c|c|}
\hline Sample & $\mathrm{Fe} 2 \mathrm{p}_{3 / 2}$ & $\mathbf{F e}$ & $\mathrm{Co} 2 p_{3 / 2}$ & Peak & Co & $\mathrm{Ni} 2 \mathrm{p}_{3 / 2}$ & Peak & $\mathrm{Ni}$ & $\% \mathrm{Fe}(\mathrm{II})$ & $\% \mathrm{Fe}(\mathrm{III})$ & $\% \mathrm{Fe}(\mathrm{III})$ & $\% \mathrm{Fe}(\mathrm{III})$ \\
\hline & eV & $\begin{array}{c}\% \\
\text { (Mass) }\end{array}$ & eV & $\%$ & $\begin{array}{c}\% \\
\text { (Mass) }\end{array}$ & $\mathrm{eV}$ & $\%$ & $\begin{array}{c}\% \\
\text { (Mass) }\end{array}$ & Oct & Total & Oct & Teth \\
\hline \multirow[t]{6}{*}{$\mathrm{NiCo}_{2} \mathrm{O}_{4} / \mathrm{Co}-\mathrm{CX}$} & & & 779.2 & 43.0 & 21.6 & 854.3 & 34.4 & 12.1 & & & & \\
\hline & & & 780.6 & 57.0 & & 855.9 & 65.6 & & & & & \\
\hline & & & 783.9 & & & 860.9 & & & & & & \\
\hline & & & 788.8 & & & 863.2 & & & & & & \\
\hline & & & 794.4 & & & 871.9 & & & & & & \\
\hline & & & 804.5 & & & 881.7 & & & & & & \\
\hline \multirow[t]{4}{*}{$\mathrm{NiCo}_{2} \mathrm{O}_{4} / \mathrm{Ni}-\mathrm{CX}$} & & & 779.2 & 43.7 & 18.7 & 854.2 & 32.3 & 11.2 & & & & \\
\hline & & & 780.6 & 56.3 & & 856.0 & 67.7 & & & & & \\
\hline & & & 784.1 & & & 860.8 & & & & & & \\
\hline & & & 788.8 & & & 863.5 & & & & & & \\
\hline \multirow[t]{8}{*}{$\mathrm{NiFe}_{2} \mathrm{O}_{4} / \mathrm{Co}-\mathrm{CX}$} & 709.9 & 22.6 & & & & 854.2 & 43.7 & 10.2 & 32.9 & 67.1 & 43.2 & 56.8 \\
\hline & 711.5 & & & & & 855.6 & 56.3 & & & & & \\
\hline & 713.4 & & & & & 860.3 & & & & & & \\
\hline & 718.7 & & & & & 862.5 & & & & & & \\
\hline & 723.2 & & & & & 871.7 & & & & & & \\
\hline & 725.1 & & & & & 873.2 & & & & & & \\
\hline & 727.1 & & & & & 877.7 & & & & & & \\
\hline & 731.8 & & & & & 880.6 & & & & & & \\
\hline \multirow[t]{4}{*}{$\mathrm{NiFe}_{2} \mathrm{O}_{4} / \mathrm{Ni}-\mathrm{CX}$} & 710.0 & 15.6 & & & & 854.3 & 39.3 & 7.8 & 21.9 & 78.1 & 50.2 & 49.8 \\
\hline & 711.2 & & & & & 855.6 & 60.7 & & & & & \\
\hline & 713.1 & & & & & 860.9 & & & & & & \\
\hline & 718.4 & & & & & 865.3 & & & & & & \\
\hline \multirow{4}{*}{$\mathrm{CoFe}_{2} \mathrm{O}_{4} / \mathrm{Co}-\mathrm{CX}$} & 723.1 & & 795.1 & & & & & & & & & \\
\hline & 724.8 & & 796.8 & & & & & & & & & \\
\hline & 727.0 & & 802.2 & & & & & & & & & \\
\hline & 732.1 & & 804.8 & & & & & & & & & \\
\hline \multirow[t]{8}{*}{$\mathrm{CoFe}_{2} \mathrm{O}_{4} / \mathrm{Ni}-\mathrm{CX}$} & 709.9 & 24.8 & 779.7 & 53.1 & 10.7 & & & 0.0 & 35.9 & 64.1 & 47.1 & 52.9 \\
\hline & 711.4 & & 781.5 & 46.9 & & & & & & & & \\
\hline & 713.3 & & 785.4 & & & & & & & & & \\
\hline & 718.4 & & 788.5 & & & & & & & & & \\
\hline & 723.1 & & 795.1 & & & & & & & & & \\
\hline & 724.9 & & 796.7 & & & & & & & & & \\
\hline & 726.7 & & 801.7 & & & & & & & & & \\
\hline & 732.6 & & 804.5 & & & & & & & & & \\
\hline
\end{tabular}

Different $\mathrm{Co} 2 \mathrm{p}_{3 / 2}$ peaks with respect to Co2p spectra peaks have been deconvoluted and assigned as the following: In the case of $\mathrm{CoFe}_{2} \mathrm{O}_{4}$ phases the peaks centred at $779.6 \pm 0.1$ correspond to $\mathrm{Co}^{2+}$ situated in tetrahedral holes whereas those centred at $781.5 \pm 0.2$ correspond to $\mathrm{Co}^{2+}$ situated in octahedral holes [30], therefore these metals deposited on the surface of the samples are forming part of the compounds type $\left(\mathrm{Co}_{\mathrm{x}}^{2+} \mathrm{Fe}_{\mathrm{y}}^{3+}\right)\left[\mathrm{Fe}_{\mathrm{z}}^{2+} \mathrm{Fe}_{1-\mathrm{y}}^{3+} \mathrm{Co}_{1-\mathrm{x}}^{2+}\right] \mathrm{O}_{4}$ where cations in parenthesis are situated in tetrahedral positions while cations in brackets are situated in octahedral positions. However, in the case of $\mathrm{NiCo}_{2} \mathrm{O}_{4}$ phases the peaks centred at $779.2 \pm 0.1$ correspond to $\mathrm{Co}^{2+}$ situated in octahedral holes whereas those centred at $780.6 \pm 0.2$ correspond to $\mathrm{Co}^{3+}$ situated in tetrahedral holes $[4,31]$.

Finally, the XPS spectra of Ni2p region shows peaks at $854.2 \pm 0.1$ y $871.7 \pm 0.2 \mathrm{eV}$ which correspond to $\mathrm{Ni}^{2+}$ as well as peaks at $855.9 \pm 0.3$ y $873.5 \pm 0.2 \mathrm{eV}$ corresponding to $\mathrm{Ni}^{3+}$ cations [31]. Therefore, XPS results show the metals as divalent or trivalent species in all the cases. Taking into account all this XPS analysis, we can conclude that the different phases that have been synthetized and supported on the different samples of this work correspond with the stoichiometries collected in Table 5. 
Table 5. Samples stoichiometries obtained from XPS.

\begin{tabular}{cc}
\hline Sample & Stoichiometry \\
\hline $\mathrm{NiCo}_{2} \mathrm{O}_{4} / \mathrm{Co}-\mathrm{CX}$ & $\left(\mathrm{Co}_{0.86} \mathrm{Ni}_{0.14}\right)\left[\mathrm{Co}_{1.14} \mathrm{Ni}_{0.86}\right]$ \\
$\mathrm{NiCo}_{2} \mathrm{O}_{4} / \mathrm{Ni}-\mathrm{CX}$ & $\left(\mathrm{Co}_{0.87} \mathrm{Ni}_{0.13}\right)\left[\mathrm{Co}_{1.13} \mathrm{Ni}_{0.87}\right]$ \\
$\mathrm{NiFe}_{2} \mathrm{O}_{4} / \mathrm{Co}-\mathrm{CX}$ & $\left.\left(\mathrm{Fe}_{0.66} \mathrm{Ni}_{0.34}\right) \mathrm{Fe}_{1.24} \mathrm{Ni}_{0.76}\right]$ \\
$\mathrm{NiFe}_{2} \mathrm{O}_{4} / \mathrm{Ni}-\mathrm{CX}$ & $\left(\mathrm{Fe}_{0.78} \mathrm{Ni}_{0.22}\right)\left[\mathrm{Fe}_{1.22} \mathrm{Ni}_{0.78}\right]$ \\
$\mathrm{CoFe}_{2} \mathrm{O}_{4} / \mathrm{Co}-\mathrm{CX}$ & $\left(\mathrm{Co}_{0.34} \mathrm{Fe}_{0.66}\right)\left[\mathrm{Fe}_{1.34} \mathrm{Co}_{0.66}\right]$ \\
$\mathrm{CoFe}_{2} \mathrm{O}_{4} / \mathrm{Ni}-\mathrm{CX}$ & $\left(\mathrm{Co}_{0.32} \mathrm{Fe}_{0.68}\right)\left[\mathrm{Fe}_{1.32} \mathrm{Co}_{0.68}\right]$ \\
\hline
\end{tabular}

For ORR application, there is a reduction peak for oxygen saturated electrolyte for both $\mathrm{NiCo}_{2} \mathrm{O}_{4} / \mathrm{Co}-\mathrm{CX}$ (Figure 6a) and $\mathrm{NiCo}_{2} \mathrm{O}_{4} / \mathrm{Ni}-\mathrm{CX}$ (Figure 6b). This reduction peak is absent when the electrolyte is saturated with nitrogen (Black line), which means that these electrodes have electroactivity toward oxygen reduction reaction. Also, as it can be seen from the linear sweep voltammograms (LSV) (Figure 7) that the electrocatalytic activity for the nickel cobaltite doped carbon xerogels is higher than that for samples doped with nickel ferrite or cobalt ferrite and the onset potential for that sample is lower because of the increase in mesoporosity that allows higher accessibility for the electrolytic ions to access the pores (Table 1). The onset potentials $E_{\text {onset }}$ for all samples are compiled in Table 6, in which the lowest onset potentials $\mathrm{E}_{\text {onset }}$ of $-0.06 \mathrm{~V}$ is obtained for $\mathrm{NiCo}_{2} \mathrm{O}_{4} / \mathrm{Co}-\mathrm{CX}$. Similar data was obtained for $\mathrm{NiCo}_{2} \mathrm{O}_{4} / \mathrm{Ni}-\mathrm{CX}$ with onset potential $\mathrm{E}_{\text {onset }}$ of $-0.07 \mathrm{~V}$. As it can be seen, samples doped with nickel ferrite and cobalt ferrite have comparable onset potentials.

Table 6. Parameters obtained from LSV at $4000 \mathrm{rpm}$ (values of $\mathrm{n}$ refer to K-L fitting for data at $-0.8 \mathrm{~V}$ ) and equivalent series resistance (ESR) calculated from the Nyquist plot.

\begin{tabular}{ccccc}
\hline Sample & Eonset & $\mathbf{n}$ & ESR \\
\cline { 2 - 2 } & $\mathbf{V}$ & & $\mathbf{\Omega}$ \\
\hline $\mathrm{NiCo}_{2} \mathrm{O}_{4} / \mathrm{Co}-\mathrm{CX}$ & -0.06 & & 4.0 & 2.74 \\
$\mathrm{NiFe}_{2} \mathrm{O}_{4} / \mathrm{Co}-\mathrm{CX}$ & -0.31 & & 2.7 & 23.26 \\
$\mathrm{CoFe}_{2} \mathrm{O}_{4} / \mathrm{Co}-\mathrm{CX}$ & -0.32 & & 2.7 & 15.90 \\
$\mathrm{NiCo}_{2} \mathrm{O}_{4} / \mathrm{Ni}-\mathrm{CX}$ & -0.07 & & 3.5 & 6.18 \\
$\mathrm{NiFe}_{2} \mathrm{O}_{4} / \mathrm{Ni}-\mathrm{CX}$ & -0.19 & & 2.6 & 10.57 \\
$\mathrm{CoFe}_{2} \mathrm{O}_{4} / \mathrm{Ni}-\mathrm{CX}$ & -0.28 & 2.2 & 22.03 \\
\hline
\end{tabular}

In order to evaluate the number of transferred electrons during the reaction for each electrocatalyst, linear sweep voltammetry was carried out at $5 \mathrm{mV} \cdot \mathrm{s}^{-1}$ at different rotating speeds from $500 \mathrm{rpm}$ to $4000 \mathrm{rpm}$, in order to apply the Koutecky-Levich model (Figure 8). The LSV for $\mathrm{NiCo}_{2} \mathrm{O}_{4} / \mathrm{Co}-\mathrm{CX}$ is presented in Figure 8a, in which the activity is promoted by increasing the rotating speed due to better diffusion of the electrolyte ions inside the pores. LSV data for $\mathrm{NiC}_{2} \mathrm{O}_{4} / \mathrm{Ni}-\mathrm{CX}$ are shown in Figure $8 \mathrm{~b}$. At the same rotating speed of $4000 \mathrm{rpm}$ (Figure $8 \mathrm{c}$ ), the activity of $\mathrm{NiCO}_{2} \mathrm{O}_{4} / \mathrm{Co}-\mathrm{CX}$ to oxygen reduction is higher than that of $\mathrm{NiCo}_{2} \mathrm{O}_{4} / \mathrm{Ni}-\mathrm{CX}$, indicating their current densities.

The data obtained from fitting the linear sweep voltammograms to the Koutecky-Levich model (Figure 9) confirms that there is a promotion in the number of electrons transferred during the oxygen reduction reaction by doping the carbon xerogels with $\mathrm{NiCo}_{2} \mathrm{O}_{4}$. For example, in case of $\mathrm{NiCo}_{2} \mathrm{O}_{4} / \mathrm{Co}-\mathrm{CX}$ (Figure 9a) the reaction takes place by the four electron pathway which is the favored one for oxygen reduction reaction (Table 6). While in case of $\mathrm{NiCo}_{2} \mathrm{O}_{4} / \mathrm{Ni}-\mathrm{CX}$ and the rest of the electrocatalysts, the reaction occurs by both two and four electrons transfer pathways.

The electrochemical impedance spectroscopy (EIS), were performed for all prepared samples using the two electrode configuration in which $6 \mathrm{M} \mathrm{KOH}$ was used as the electrolyte in order to evaluate the electrode resistance and equivalent series resistance ESR (Figure 10). The activity of nickel cobaltite doped carbon xerogels toward ORR can also be attributed to the good electrical conductivity of nickel cobaltite relative to nickel ferrite or cobalt ferrite [32] as it can be seen from the Nyquist plots with 
lower electrode resistance for these samples (Figure 10). The equivalent series resistance ESR for the prepared samples was calculated from the Nyquist plot and is compiled in Table 6. Figure 10a shows the Nyquist plots for cobalt doped carbon xerogels (Co-CX) with the three bimetal oxides, the lowest ESR was obtained for $\mathrm{NiCo}_{2} \mathrm{O}_{4} / \mathrm{Co}-\mathrm{CX}$ which equals to $2.74 \Omega$ that reveals higher electrical conductivity and higher electrochemical performance to oxygen reduction. Likewise in case of nickel doped carbon xerogels (Ni-CX) (Figure 10b), the lowest ESR was achieved for $\mathrm{NiCo}_{2} \mathrm{O}_{4} / \mathrm{Ni}-\mathrm{CX}$ with $6.18 \Omega$. Moreover, comparing $\mathrm{Co}-\mathrm{CX}$ and $\mathrm{Ni}-\mathrm{CX}$ doped $\mathrm{NiCo}_{2} \mathrm{O}_{4}$ (Figure 10c), the activity of carbon xerogels doped with cobalt is higher than that of nickel doped one because of the development of mesoporosity and lower electrode resistance, this tendency is in good agreement with our previous published work [23]. On the other hand, by comparing our electrocatalyst $\mathrm{NiCo}_{2} \mathrm{O}_{4} / \mathrm{Co}-\mathrm{CX}$ with the ones in previously published materials such as $\mathrm{NiCo}_{2} \mathrm{O}_{4}$-rGO hybrid nanosheets in the same conditions [12], lower onset potential of $-0.06 \mathrm{~V}$ was found compared to $-0.073 \mathrm{~V}$ vs. $\mathrm{Ag} / \mathrm{AgCl}$ indicating higher electrocatalytic activity to ORR. In addition, the ORR current density at a rotating speed of $2500 \mathrm{rpm}$ and at $-0.8 \mathrm{~V} \mathrm{vs}$. $\mathrm{Ag} / \mathrm{AgCl}$ for $\mathrm{NiCo}_{2} \mathrm{O}_{4} / \mathrm{Co}-\mathrm{CX}$ is about $-6.3 \mathrm{~mA} \cdot \mathrm{cm}^{-2}$ while for $\mathrm{NiCo}_{2} \mathrm{O}_{4}-\mathrm{rGO}$ is about $-2.0 \mathrm{~mA} \cdot \mathrm{cm}^{-2}$. The higher activity for ORR is also confirmed with the calculated number of electrons transferred which in case of $\mathrm{NiCo}_{2} \mathrm{O}_{4} / \mathrm{Co}-\mathrm{CX}$ nanocomposite is $\mathrm{n}=4.0$ while for $\mathrm{NiCo}_{2} \mathrm{O}_{4}-\mathrm{rGO}$ hybrid nanosheets $\mathrm{n}=3.8$.

\section{Conclusions}

Binary metal oxides doped carbon xerogels were successfully prepared by the sol-gel process followed by a designed hydrothermal method. For all the prepared materials, the metal cations exist as divalent and trivalent species that occupy both the corresponding tetrahedral and octahedral positions in the crystal structure. The presence of metal cations inside the carbon xerogel structure develops the mesoporosity that makes these materials promising electrocatalysts for ORR. Nickel cobaltite doped carbon xerogels developed a new nano-needle like structure morphology and showed the highest electrocatalytic performance and lowest onset potential for oxygen reduction reaction. In general, development of mesoporosity of carbon xerogel together with increasing its electrical conductivity by bimetal oxides doping, especially nickel cobaltite based phase, improved the electrocatalytic performance in oxygen reduction reaction.

Supplementary Materials: The following are available online at http://www.mdpi.com/1996-1944/12/15/2446/s1, Figure S1: Figure S1: Nitrogen isotherms at $-196{ }^{\circ} \mathrm{C}$ for samples: (a) $\mathrm{NiFe}_{2} \mathrm{O}_{4} / \mathrm{Co}-\mathrm{CX}, \square$; $\mathrm{NiCo}_{2} \mathrm{O}_{4} / \mathrm{Co}-\mathrm{CX}, \diamond$; $\mathrm{CoFe}_{2} \mathrm{O}_{4} / \mathrm{Co}-\mathrm{CX}, \bigcirc$ and (b) $\mathrm{NiFe}_{2} \mathrm{O}_{4} / \mathrm{Ni}-\mathrm{CX}$, $\square ; \mathrm{NiCo}_{2} \mathrm{O}_{4} / \mathrm{Ni}-\mathrm{CX}, \diamond ; \mathrm{CoFe}_{2} \mathrm{O}_{4} / \mathrm{Ni}-\mathrm{CX}, \mathrm{O}$. Adsorption curve-open symbols; desorption curve-closed symbols. Figure S2: EDXS analysis carried out on sample $\mathrm{NiCo}_{2} \mathrm{O}_{4}-\mathrm{CoCX}$.

Author Contributions: Conceptualization: all the authors; methodology: A.A.; analysis and discussion of results: all the authors; XPS data analysis: F.C.-M.; writing—all the authors; project administration: A.A. and A.F.P.-C.; funding acquisition: A.A. and A.F.P.-C.

Funding: This research was funded by science and technology development fund [STDF] grant number [STF-25402] and from the project P12-RNM-2892 (Junta de Andalucía).

Acknowledgments: The authors greatly acknowledge the financial support from STDF and from Junta de Andalucía.

Conflicts of Interest: The authors declare no conflict of interest.

\section{References}

1. Winter, M.; Brodd, R.J. What are batteries, fuel cells and supercapacitors. Chem. Rev. 2004, 104, 4245-4270. [CrossRef] [PubMed]

2. Hoogers, G. Fuel Cell Technology Handbook; CRC Press: Boca Raton, FL, USA, 2003; pp. 4-23.

3. Carrette, L.; Friedrich, K.A.; Stimming, U. Fuel cells: principles, types fuels and applications. ChemPhysChem 2000, 1, 162-193. [CrossRef]

4. Mahala, C.; Basu, M. Nanosheets of $\mathrm{NiCo}_{2} \mathrm{O}_{4} / \mathrm{NiO}$ as efficient and stable electrocatalyst for oxygen evolution reaction. ACS Omega 2017, 2, 7559-7567. [CrossRef] 
5. Shin, D.; An, X.; Choun, M.; Lee, J. Effect of transition metal induced pore structure on oxygen reduction reaction of electrospun fibrous carbon. Catal. Today 2016, 260, 82-88. [CrossRef]

6. Wang, Y.J.; Zhao, N.; Fang, B.; Li, H.; Bi, X.T.; Wang, H. Carbon-supported Pt-based alloy electrocatalysts for the oxygen reduction reaction in polymer electrolyte membrane fuel cells: particle size, shape, and composition manipulation and their impact to activity. Chem. Rev. 2015, 115, 3433-3467. [CrossRef]

7. Huang, X.; Zhao, Z.; Cao, L.; Chen, Y.; Zhu, E.; Lin, Z.; Li, M.; Yan, A.; Zettl, A.; Wang, Y.M. High-performance transition metal-doped $\mathrm{Pt}_{3} \mathrm{Ni}$ octahedra for oxygen reduction reaction. Science 2015, 348, 1230-1234. [CrossRef] [PubMed]

8. Jayasayee, K.; Van Veen, J.R.; Manivasagam, T.G.; Celebi, S.; Hensen, E.J.; De Bruijn, F.A. Oxygen reduction reaction (ORR) activity and durability of carbon supported $\mathrm{PtM}(\mathrm{Co}, \mathrm{Ni}, \mathrm{Cu})$ alloys: Influence of particle size and non-noble metals. Appl. Catal. B Environ. 2012, 111, 515-526. [CrossRef]

9. Paulus, U.; Wokaun, A.; Scherer, G.; Schmidt, T.; Stamenkovic, V.; Radmilovic, V.; Markovic, N.; Ross, P. Oxygen reduction on carbon-supported Pt-Ni and Pt-Co alloy catalysts. J. Phys. Chem. B 2002, 106, 4181-4191. [CrossRef]

10. Wang, B. Recent development of non-platinum catalysts for oxygen reduction reaction. J. Power Sources 2005, 152, 1-15. [CrossRef]

11. Wang, H.; Holt, C.M.; Li, Z.; Tan, X.; Amirkhiz, B.S.; Xu, Z.; Olsen, B.C.; Stephenson, T.; Mitlin, D. Graphene-nickel cobaltite nanocomposite asymmetrical supercapacitor with commercial level mass loading. Nano Res. 2012, 5, 605-617. [CrossRef]

12. Zhang, G.; Xia, B.Y.; Wang, X.; Lou, X.W. Strongly coupled $\mathrm{NiCo}_{2} \mathrm{O}_{4}-\mathrm{rGO}$ hybrid nanosheets as a methanol-tolerant electrocatalyst for the oxygen reduction reaction. Adv. Mater. 2014, 26, 2408-2412. [CrossRef] [PubMed]

13. Chu, Y.-Q.; Fu, Z.-W.; Qin, Q.-Z. Cobalt ferrite thin films as anode material for lithium ion batteries. Electrochim. Acta 2004, 49, 4915-4921. [CrossRef]

14. Yasmin, S.; Cho, S.; Jeon, S. Electrochemically reduced graphene-oxide supported bimetallic nanoparticles highly efficient for oxygen reduction reaction with excellent methanol tolerance. Appl. Surf. Sci. 2018, 434, 905-912. [CrossRef]

15. Gong, K.; Du, F.; Xia, Z.; Durstock, M.; Dai, L. Nitrogen-doped carbon nanotube arrays with high electrocatalytic activity for oxygen reduction. Science 2009, 323, 760-764. [CrossRef]

16. Pekala, R.; Alviso, C.; Kong, F.; Hulsey, S. Aerogels derived from multifunctional organic monomers. J. Non-Cryst. Solids 1992, 145, 90-98. [CrossRef]

17. Pekala, R. Organic aerogels from the polycondensation of resorcinol with formaldehyde. J. Mater. Sci. 1989, 24, 3221-3227. [CrossRef]

18. EL-Deeb, M.M.; El Rouby, W.M.; Abdelwahab, A.; Farghali, A.A. Effect of pore geometry on the electrocatalytic performance of nickel cobaltite/carbon xerogel nanocomposite for methanol oxidation. Electrochim. Acta 2018, 259, 77-85. [CrossRef]

19. Zapata-Benabithe, Z.; Carrasco-Marín, F.; de Vicente, J.; Moreno-Castilla, C. Carbon xerogel microspheres and monoliths from resorcinol-formaldehyde mixtures with varying dilution ratios: Preparation, surface characteristics, and electrochemical double-layer capacitances. Langmuir 2013, 29, 6166-6173. [CrossRef] [PubMed]

20. Pérez-Cadenas, A.F.; Ros, C.H.; Morales-Torres, S.; Pérez-Cadenas, M.; Kooyman, P.J.; Moreno-Castilla, C.; Kapteijn, F. Metal-doped carbon xerogels for the electro-catalytic conversion of $\mathrm{CO}_{2}$ to hydrocarbons. Carbon 2013, 56, 324-331. [CrossRef]

21. Abdelwahab, A.; Castelo-Quibén, J.; Pérez-Cadenas, M.; Elmouwahidi, A.; Maldonado-Hódar, F.J.; Carrasco-Marín, F.; Pérez-Cadenas, A.F. Cobalt-Doped Carbon Gels as Electro-Catalysts for the Reduction of $\mathrm{CO}_{2}$ to Hydrocarbons. Catalysts 2017, 7, 25. [CrossRef]

22. Moreno-Castilla, C.; Maldonado-Hódar, F. Carbon aerogels for catalysis applications: An overview. Carbon 2005, 43, 455-465. [CrossRef]

23. Abdelwahab, A.; Castelo-Quibén, J.; Vivo-Vilches, J.F.; Pérez-Cadenas, M.; Maldonado-Hódar, F.J.; Carrasco-Marín, F.; Pérez-Cadenas, A.F. Electrodes Based on Carbon Aerogels Partially Graphitized by Doping with Transition Metals for Oxygen Reduction Reaction. Nanomaterials 2018, 8, 266. [CrossRef] [PubMed] 
24. Maldonado-Hódar, F.; Moreno-Castilla, C.; Pérez-Cadenas, A. Surface morphology, metal dispersion, and pore texture of transition metal-doped monolithic carbon aerogels and steam-activated derivatives. Microporous Mesoporous Mater. 2004, 69, 119-125. [CrossRef]

25. Job, N.; Pirard, R.; Marien, J.; Pirard, J.-P. Synthesis of transition metal-doped carbon xerogels by solubilization of metal salts in resorcinol-formaldehyde aqueous solution. Carbon 2004, 42, 3217-3227. [CrossRef]

26. Moreno-Castilla, C.; Maldonado-Hódar, F.; Pérez-Cadenas, A. Physicochemical surface properties of Fe, Co, $\mathrm{Ni}$, and Cu-doped monolithic organic aerogels. Langmuir 2003, 19, 5650-5655. [CrossRef]

27. Abdelwahab, A.; Castelo-Quibén, J.; Pérez-Cadenas, M.; Maldonado-Hódar, F.J.; Carrasco-Marín, F.; Pérez-Cadenas, A.F. Insight of the effect of graphitic cluster in the performance of carbon aerogels doped with nickel as electrodes for supercapacitors. Carbon 2018, 139, 888-895. [CrossRef]

28. Chmiola, J.; Yushin, G.; Dash, R.; Gogotsi, Y. Effect of pore size and surface area of carbide derived carbons on specific capacitance. J. Power Sources 2006, 158, 765-772. [CrossRef]

29. Gryglewicz, G.; Machnikowski, J.; Lorenc-Grabowska, E.; Lota, G.; Frackowiak, E. Effect of pore size distribution of coal-based activated carbons on double layer capacitance. Electrochim. Acta 2005, 50, 1197-1206. [CrossRef]

30. de Lima Alves, T.M.; Amorim, B.F.; Torres, M.A.M.; Bezerra, C.G.; de Medeiros, S.N.; Gastelois, P.L.; Outon, L.E.F.; de Almeida Macedo, W.A. Wasp-waisted behavior in magnetic hysteresis curves of $\mathrm{CoFe}_{2} \mathrm{O}_{4}$ nanopowder at a low temperature: experimental evidence and theoretical approach. RSC Adv. 2017, 7, 22187-22196. [CrossRef]

31. Yang, Y.; Zeng, D.; Yang, S.; Gu, L.; Liu, B.; Hao, S. Nickel cobaltite nanosheets coated on metal-organic framework-derived mesoporous carbon nanofibers for high-performance pseudocapacitors. J. Colloid Interface Sci. 2019, 534, 312-321. [CrossRef]

32. Jokar, E.; Shahrokhian, S. Synthesis and characterization of $\mathrm{NiCo}_{2} \mathrm{O}_{4}$ nanorods for preparation of supercapacitor electrodes. J. Solid State Electrochem. 2015, 19, 269-274. [CrossRef]

(C) 2019 by the authors. Licensee MDPI, Basel, Switzerland. This article is an open access article distributed under the terms and conditions of the Creative Commons Attribution (CC BY) license (http://creativecommons.org/licenses/by/4.0/). 